\title{
1 Reactivation of the Pleistocene trans-Arabian Wadi ad 2 Dawasir fluvial system (Saudi Arabia) during the 3 Holocene humid phase
}

5 Albert Matter ${ }^{\mathrm{a}}$, Ayman Mahjoub ${ }^{\mathrm{b}}$, Eike Neubert ${ }^{\mathrm{c}}$, Frank Preusser ${ }^{\mathrm{d}, \mathrm{e}}{ }^{*}$, Antje Schwalb ${ }^{\mathrm{f}}$, Sönke Szidat ${ }^{\mathrm{g}}$, 6 Gerwin Wulf ${ }^{\text {e }}$

${ }^{a}$ Institute of Geological Sciences, University of Bern, Balterzerstrasse 1+3, 3012 Bern, Switzerland

${ }^{\mathrm{b}}$ Saudi Geological Survey, P.O.Box 54141, Jeddah 21514, Kingdom of Saudi Arabia

$10{ }^{\mathrm{C}}$ Natural History Museum Bern, Bernastrasse 15, 3005 Bern, Switzerland

$11{ }^{d}$ Previously at: Department of Physical Geography and Quaternary Geology, Stockholm University, 10690 Stockholm, Sweden

$12{ }^{\mathrm{e}}$ Institute of Earth and Environmental Sciences, University of Freiburg, Albertstraße 23b, 79104 Freiburg, Germany

$13{ }^{\mathrm{f}}$ Institut für Geosysteme und Bioindikation, Technische Universität Braunschweig, 38106 Braunschweig, Germany 14 g Department of Chemistry and Biochemistry \& Oeschger Centre for Climate Change Research, University of Bern, Freiestrasse 3 ,

$16 *$ corresponding author. E-mail: frank.preusser@geologie.uni-freiburg.de

\section{$\underline{\text { Accepted version }}$}

21 Published in

22 Geomorphology 270 (2016) 88-101

23 http://dx.doi.org/10.1016/i.geomorph.2016.07.013 
25 Abstract - The Wadi ad Dawasir fluvial system in central Saudi Arabia is investigated using

26 remote sensing and sedimentology, in combination with bio-proxy analyses (molluscs and

27 ostracods). Age control is provided by radiocarbon as well as luminescence dating, using both

28 quartz and feldspar grains. It is shown that the fluvial system was active from the Asir

29 Mountains across the partially sand-covered interior of the Arabian Peninsula to the Arabian

30 Gulf during the Holocene humid period. Sedimentology and faunal analysis reveal the

31 presence of perennial streams and a permanent freshwater lake in the distal reach of the

32 Dawasir system that are synchronous with fluvial accumulation in the headwaters of its major

33 tributary, Wadi Tathlith. The increased runoff during the Holocene led to a re-activation of

34 streams that largely followed pre-existing Late Pleistocene courses and eroded into older

35 sediments. The absence of Holocene lakes in most of the Rub' al-Khali implies that trans-

36 Arabian rivers were mainly fed by precipitation in the Asir Mountains. Monsoonal rainfall was

37 apparently stronger there as well as in the northern, south-eastern and southern part of the

38 Arabian Peninsula (southern Yemen and Oman), but it apparently did not directly affect the

39 interior during the Holocene. The palaeoenvironmental reconstruction shows a narrow trans-

40 Arabian green freshwater corridor as the result of phases of sustained flow lasting up to several

41 centuries. The permanent availability of water and subsistence for wildlife provided a

42 favourable environment for human occupation as documented by Neolithic stone tools that are

43 found all along Wadi ad Dawasir.

44 Keywords: Fluvial, Holocene, Arabia, Humid period 


\section{Introduction}

Four major sand seas (Ar Rub' al-Khali, Ad Dahna, Al Jafura, and An Nafud) cover an area of $765,000 \mathrm{~km}^{2}$ on the Arabian Peninsula (Wilson, 1973), by this comprising $36 \%$ of the territory of the Kingdom of Saudi Arabia. They are the most prominent evidence of the present arid to hyper-arid climate, with rainfall of less than $100 \mathrm{~mm} \mathrm{a}^{-1}$ in the interior of the peninsula. Higher rainfall levels are restricted to the Hedjaz-Asir Plateau and the Yemeni highlands (Almazroui et al., 2012). This pattern is tied to the Hadley cell circulation and its local manifestation, the monsoon system, which are key components responsible for the climate of Arabia (Webster, 2005). At present, the source of rainfall reaching SW Arabia and the coast of Dhofar is the African summer monsoon rather than the Indian Ocean Summer Monsoon as previously assumed (Fleitmann et al., 2007; Bosmans et al., 2014; Enzel et al., 2015; Jennings et al., 2015). The winter months are characterized by a stable high pressure system, clear skies and mild temperatures. During this time of the year Mediterranean cyclones track across the Arabian Peninsula and reach as far as Oman, giving rise to low levels of rainfall.

Little palaeoclimate research was carried out in Saudi Arabia until recently, although the joint mapping project of the Kingdom of Saudi Arabia and the U.S. Geological Survey revealed compelling geomorphologic evidence of much wetter episodes during the Quaternary (Brown et al., 1989). A fluvial-style drainage network with large gravel accumulations east of the Hejaz-Asir Mountains (Holm, 1960) and lake deposits within the dunes of the Rub' al-Khali and the Nafud were investigated subsequently in detail by McClure $(1976,1984)$ and Schulz and Whitney (1986), respectively. The observation of gravel plains and aquatic molluses in the lower reaches of Wadi ad Dawasir had already led Philby (1933) to conclude that this river system and possibly others had reached the Arabian Gulf. Brown (1960) argued that gravel terraces 20 to 60 $m$ above the present thalweg of Wadi Sahba and Wadi Batin represent remnants of approximately $1 \mathrm{~km}$ wide Pleistocene river courses. Despite their low gradient of about $1 \mathrm{~m} \mathrm{~km}^{-1}$, these rivers transported coarse clasts indicating a high stream power. For example, Holm (1961, cited in Edgell, 2006) reported quartzite boulders measuring up to $25 \mathrm{~cm}$ in size in a palaeochannel of Wadi Sahba ca. $95 \mathrm{~km}$ from the coast, i.e. about $600 \mathrm{~km}$ downstream of the source terrain in the Arabian Shield. Furthermore, these palaeorivers built-up conglomerate megafans before entering the Arabian Gulf (Hötzl 
et al., 1978a; Edgell, 2006). Based on K-Ar ages of two basalt flows encasing a gravel layer in the Wadi ad Dawasir, Anton (1984) argued that the major trans-Arabian wadis depicted in his palaeohydrological map were incised between 3 and 1 million years ago.

However, systematic knowledge about these obvious palaeoenvironmental changes resulted from studies carried out mainly in the adjacent countries (Oman, United Arab Emirates, Yemen) on stalagmites (Burns et al., 2001; Fleitmann et al., 2003a,b, 2004, 2005, 2007, 2011; Neff et al., 2001), lake sediments (Parker et al., 2004, 2006; Lézine et al., 1998; Radies et al., 2005; Petit-Maire et al., 2010; Rosenberg et al., 2011a; Catlett, 2014), aeolian dunes (e.g. Juyal et al., 1998; Goudie et al., 2000; Preusser et al., 2002; Radies et al., 2004) and fluvial deposits (Blechschmidt et al., 2009; Berger et al., 2012; Hoffmann et al., 2015; Parton et al., 2015). Advances in geochronology, especially Optically Stimulated Luminescence (OSL) and Uranium-Thorium $\left({ }^{234} \mathrm{U} /{ }^{230} \mathrm{Th}\right)$ methods, now permit dating these archives beyond the dating limit of radiocarbon and, hence, reconstruction of the temporal and spatial framework of the environmental history. The climate record derived from the previously mentioned archives reveals significant hydrological changes with pronounced humid periods in southern Arabia during Marine Isotope Stages (MIS) 1, 5a, 5e, 7 and 9, and further though less well-documented humid phases during MIS 3 and 11. It is assumed that high summer insolation during these periods strengthened the monsoon and pulled the associated rainfall belt northward into the interior of Arabia. ${ }^{18} \mathrm{O}$ data from stalagmites suggest that the highest precipitation levels occurred during MIS 5e and the lowest during MIS 1 (Fleitmann et al., 2011).

In the past decade, the number of studies on the palaeoenvironment of Saudi Arabia has increased markedly due to a more open political situation allowing access to remote areas such as the Rub' al-Khali. Many of these studies have been carried out in the context of investigating the human dispersal Out-of-Africa models because knowledge of the palaeohydrology and the timing of humid phases is essential for understanding the migration of anatomically modern humans (AMH) into Arabia and beyond (e.g. Petraglia et al., 2011). This range expansion was only possible when the Arabian deserts, which represented a barrier for AMH, turned into a 'Green Arabia' with sufficient surface water and nutrition available during pluvial phases. Research 
109 has focused mainly on palaeolakes in the Rub' al-Khali (Rosenberg et al., 2011b;

110 Crassard et al., 2013; Matter et al., 2015, Groucutt et al., 2015), the Nafud (Petraglia et

111 al., 2012, Rosenberg et al., 2013; Hilbert et al., 2014; Scerri et al., 2015; Stimpson et

112 al., 2015) and Tayma (Ginau et al., 2012; Engel et al., 2012), whereas only two modern

113 studies have dated stalagmites and fluvial deposits, respectively. The stalagmites of

114 central and northern Saudi Arabia turned out to be $400 \mathrm{ka}$ old or older, indicating that

115 rainfall was too low or sporadic to allow growth of stalagmites in the past $400 \mathrm{ka}$

116 (Fleitmann et al., 2004). The first luminescence-dated fluvial sediments in the

117 headwaters of Wadi as Sahba were interpreted to reflect humid events at ca. $54 \mathrm{ka}$, ca.

$11839 \mathrm{ka}$ (corresponding to MIS 3), and ca. $0.8 \mathrm{ka}$ (McLaren et al., 2009).

119 Breeze et al. (2015) demonstrated the potential of combined remote sensing and 120 geographic information system (GIS) techniques to map palaeodrainage networks and

121 palaeolakes across vast areas in much greater detail and with improved accuracy

122 compared to earlier palaeodrainage maps of Anton (1984) and Edgell (1990, 2006).

123 Furthermore, climate model simulations provide useful information when validated

124 against field data to better understand the functioning of climate change. The results of 125 a set of simulations carried out by Jennings et al. (2015) confirm that the Arabian

126 Peninsula was wettest during MIS 5e and that lesser amounts of precipitation occurred 127 during MIS 5c and MIS 3. Moreover, they support the results of earlier simulation 128 experiments by Herold and Lohmann (2009) that the African monsoon rather than the 129 Indian Summer Monsoon was the source of higher rainfall. This is in accord with the 130 spatial and temporal distribution of lakebeds in southern Arabia. The fact that

131 Pleistocene but no Holocene palaeolakes occur in the interior of the Rub' al-Khali

132 suggests that the monsoonal rainfall belt migrated farther onto the Peninsula in the

133 Pleistocene than during the Holocene (e.g. Rosenberg et al., 2011b; Matter et al.,

134 2015). Enzel et al. (2015) challenge this interpretation based on a re-analysis of

135 published Holocene lacustrine records. They argue that: a) the palaeolakes represent

136 marsh environments requiring a much lesser annual rainfall to be sustained than open

137 lakes, and b) the intensification of rainfall is not related to a northward shift of the

138 Intertropical Convergence Zone (ITCZ) and the Indian Summer Monsoon but to a

139 slight landward expansion of the African Monsoon across the Red Sea with uplift of

140 the moist air over the Yemeni - Asir highlands associated with modest rains feeding 
141 the downstream wetlands. If this was the case, then the drainage systems must have experienced a major reactivation.

143 In this study, we investigate this hypothesis using a multi-proxy approach to

144 reconstruct the evolution of the palaeodrainage of Wadi ad Dawasir, one of the major

145 trans-Arabian wadis. As palaeodrainage systems respond sensitively to climate

146 changes that affect precipitation, runoff and fluvial style, we first determine the

147 catchment area and reconstruct the drainage pattern by remote sensing techniques. In

148 order to get a more complete view of the area, the adjacent Wadi as Sahba system is

149 included in the analysis. We then investigate selected sedimentary sections in the

150 proximal and distal reaches of the Wadi ad Dawasir system and determine their facies,

151 fossil content (molluscs and ostracods), and age (radiocarbon and luminescence

152 dating). The ultimate goal is to establish a relationship between geomorphology, facies

153 and runoff within a robust geochronological framework. With the above, we aim to

154 better understand the environmental conditions in the central part of the Arabian

155 Peninsula, for which very little information is available at the moment. The newly

156 gathered information will be crucial for cross-checking atmospheric circulation models

157 as well as for better characterization of past environments as important in the context

158 of early human habitation and dispersal through the region.

160 2. Methods

\subsection{Remote sensing and field methods}

162 A GIS environment was implemented to analyse the Wadi ad Dawasir and Wadi as

163 Sahba palaeodrainage systems and related catchment areas. ArcGIS 10 was applied for

164 geospatial analyses of digital elevation models (DEMs) and to analyse multispectral

165 data for further mapping. Digital elevation data from the Shuttle Radar Topography

166 Mission (SRTM; Farr and Kobrick, 2000; Rabus et al., 2003; Farr et al., 2007) with a

167 resolution of 3 arc-second ( $\sim 90 \mathrm{~m}$ at the equator) are provided by the Global Land

168 Cover Facility (GLCF) for download. SRTM 2.1 data were used as base data to create

169 a DEM mosaic of the Arabian Peninsula with a cell size of 90 x 90 m (Fig. 1A).

170 During processing, SRTM data voids were filled with elevation data from the

171 Advanced Spaceborne Thermal Emission and Reflection Radiometer (ASTER) Global 
172 Digital Elevation Model Version 2 (GDEM V2) (Abrams et al., 2010, 2015;

173 Tachikawa et al., 2011). To avoid possible discontinuous drainage networks in the

174 following processing steps, all sinks within the resulting DEM were removed to get a

175 DEM without depressions. Flow direction and flow accumulation were then derived

176 using the eight-direction (D8) flow model by Jenson and Domingue (1988). A drainage

177 network was delineated by applying a threshold value to the flow accumulation raster

178 that defines a minimum required contributing upstream area of a cell as a stream. With

179 regard to the large area of interest (Fig.1B), a contributing catchment area of $150 \mathrm{~km}^{2}$

180 was found appropriate to show only major stream systems while maintaining clarity.

181 SRTM-derived drainage in large sand seas, such as the Rub' al-Khali, often shows

182 particularly dense channel networks in interdune depressions although no fluvial

183 landforms are visible (e.g. Petraglia et al., 2012; Crassard et al., 2013; Stimpson et al.,

184 2015; Breeze et al., 2015). Considering the potential for errors, such peculiar dune field

185 drainage patterns were removed from the drainage network. The western part of the

186 area of interest is characterized by the depression of Sahl Rakbah, an internal drainage

187 basin that is considered to be an area of rift-related subsidence (Camp and Roobol,

188 1989, 1991). Such large sink areas deliver erroneous, straight-running stream lines

189 within the derived drainage network and thus were also removed. The resulting

190 modified drainage system will be termed the 'calculated drainage' in the following. In

191 addition, watersheds and catchment areas of the complete Wadi ad Dawasir and Wadi

192 as Sahba systems were determined by combining the derived flow direction with

193 defined outlet points of the watersheds (pour points) (Fig. 1B).

194 In areas with only minor or incomplete sand coverage, palaeodrainage systems can be

195 traced using multispectral image data (Fig. 2A-C). Landsat 7 Enhanced Thematic

196 Mapper Plus (ETM+) data with a spatial resolution of 30 m (e.g. Goward et al., 2001)

197 were used to determine and map recent and palaeostream systems in addition to the

198 calculated drainage. True and false colour composites (FCC) were generated. In the

199 process, composites were created in such a way that the different Landsat bands were

200 assigned to the intensities of red, green and blue (RGB) components of a colour image.

201 A band combination of 7, 4, $2(7=$ Red, $4=$ Green, $2=$ Blue $)$ were found to be most

202 suitable to detect palaeochannels within the mapping area (Fig. 2B, C). 
203 Digital elevation data and derived hillshade images were additionally used to retrace 204 drainage systems that could not be unequivocally determined by Landsat images, for 205 example if underlying palaeochannels led to a region of inverted topography (Fig. 2D). 206 As a result, unambiguously identified stream systems were classified as 'mapped', 207 whereas incomplete or patchy channels with still recognizable flow directions were 208 classified as 'inferred' (Fig. 1B, 2C). It has to be considered that the mapped 209 palaeodrainage system was inferred in a qualitative fashion and thus does not allow 210 any quantitative conclusions concerning contributing catchment areas or relative age 211 determinations.

212 Sedimentary characteristics were determined on six measured sections in the distal part 213 of Wadi ad Dawasir and two outcrops in the proximal part of Wadi Tathlith, which is 214 one of the major tributaries (Fig. 1B, 3). The sections in the distal reach were logged 215 using standard sediment techniques in hand-dug pits, in a trench bulldozed across a 216 palaeochannel at site 4213.3, and at an outcrop site 4214.3 shown in Fig. 1B. Grain

217 size was estimated with a visual comparator. The collected macrofossil specimens are 218 housed in the malacological voucher collection of the Natural History Museum in 219 Bern, Switzerland. Ostracods were extracted by washing sediment samples through a 220 sieve with a mesh width of $0.2 \mathrm{~mm}$. The residue was dried and the specimens picked 221 under a binocular microscope.

\subsection{Radiocarbon dating}

224 Radiocarbon dating was performed on shells of Melanoides tuberculata and Unio 225 tigridis from four samples as well as one sample of Bulinus sp. with the accelerator 226 mass spectrometer (AMS) MICADAS at the Laboratory for the Analysis of

227 Radiocarbon with AMS (LARA) at the University of Bern (Szidat et al., 2014).

228 Potential contaminants on the surface of the shells, including organic impurities and 229 recrystallized carbonates, were removed by sequential treatment with $30 \%$ hydrogen 230 peroxide and $0.12 \mathrm{~mol} / \mathrm{L}$ hydrochloric acid at room temperature. Afterwards, the 231 samples were acidified with concentrated phosphoric acid and transformed into AMS 232 target material using automated graphitization equipment connected to a carbonate 233 handling system (Wacker et al., 2013). A ${ }^{14} \mathrm{C}$-free material (IAEA-C1) and a standard 
234 with a certified ${ }^{14} \mathrm{C}$ value (IAEA-C2) were measured together with the unknown 235 samples for normalization. Measurement results were corrected for background from

236 the chemical treatment using shells from a sediment sample with an age $\sim 100 \mathrm{ka}$ 237 according to luminescence dating. Calendar ages were deduced from uncalibrated ${ }^{14} \mathrm{C}$ 238 ages using the IntCal13 calibration curve (Reimer et al., 2013) and the results are 239 shown on Table 1. The ages derived from the two species are within the statistical error 240 for all samples except sample 4213.3.

241 XRD measurements were performed on a Panalytical XPertPRO MPD with $\mathrm{Cu}$ 242 radiation at $40 \mathrm{~mA} / 40 \mathrm{kV}$ using aliquots of the fine ground material prepared for ${ }^{14} \mathrm{C}$ 243 analysis mounted on silica plates. The purpose of these analyses is to verify if the 244 aragonitic shells had undergone recrystallization that would have altered their real age. 245 All samples consist of $>99 \%$ aragonite, except the shell of Melanoides tuberculata of 246 sample 4213.3 that included $2.3 \%$ calcite. This sample is considered as an outlier in the 247 discussion of the results.

\subsection{Luminescence dating}

250 Samples for dating by OSL, Infrared Stimulated Luminescence (IRSL) and post-IR 251 IRSL ( $\mathrm{pIR}$ ) were taken from sandy beds by forcing a steel tube into a cleaned exposure 252 surface. The material from the steel tubes was transferred into opaque plastic bags and 253 sent to the laboratory at Stockholm University. Sample preparation followed standard 254 procedures including removal of carbonates using $\mathrm{HCl}$, sieving (retrieving 200-250 $\mu \mathrm{m})$ and density separation of a K-feldspar $\left(\delta<2.58 \mathrm{~g} \mathrm{~cm}^{-3}\right)$ and quartz $\left(\delta<2.70 \mathrm{~g} \mathrm{~cm}^{-}\right.$ ${ }^{3}, \delta>2.58 \mathrm{~g} \mathrm{~cm}^{-3}$ ) fraction, the latter being subsequently etched by $40 \% \mathrm{HF}$ ( $60 \mathrm{~min}$ ),

257 followed by $\mathrm{HCl}$ treatment $(>120 \mathrm{~min}$ ) to dissolve fluorites. The final separates were 258 fixed on stainless steel discs using silicon spray covering an area of a diameter of ca. 1 $259 \mathrm{~mm}$. This represents a few dozen grains on each aliquot. As the amount of grains with 260 suitable grain size was relatively low, only 12 feldspar and 24 quartz aliquots have 261 been prepared per sample.

262 Measurements were conducted using a Freiberg Instruments Lexsyg Research 263 luminescence reader (Richter et al., 2013). Stimulation was provided by LEDs with an 
264 emission peak at $458 \mathrm{~nm}$ for quartz $\left(60 \mathrm{~mW} \mathrm{~cm}^{-2}\right)$ and a laser diode at $850 \mathrm{~nm}$ for

265 feldspar $\left(150 \mathrm{~mW} \mathrm{~cm}^{-2}\right)$. For quartz, detection was at $380 \mathrm{~nm}$ with the combination of a

266 Hoya U-340 (2.5 mm) and a Delta DP 365/50 interference filter (5 mm). Detection for

267 feldspar was centred at $410 \mathrm{~nm}$ using a Schott BG-39 (3 mm) together with an AHF

268 BrightLine HC 414/46 interference filter (3.5 mm). Determination of Equivalent Dose

$269\left(D_{e}\right)$ followed the Single Aliquot Regenerative Dose (SAR) protocol of Murray and

270 Wintle (2000) for quartz, with a preheat at $230^{\circ} \mathrm{C}$ for $10 \mathrm{~s}$ and stimulation at $125^{\circ} \mathrm{C}$ for

$27160 \mathrm{~s}$. The first $0.4 \mathrm{~s}$ of the OSL signal were integrated with the integral 50-60 s

272 subtracted as background. For feldspar, the pIR protocol of Reimann and Tsukamoto

273 (2012) was used, with a preheat at $180^{\circ} \mathrm{C}$ for $30 \mathrm{~s}$ followed by an initial IR stimulation

274 for $100 \mathrm{~s}$ at $50^{\circ} \mathrm{C}$ (IRSL) and a subsequent stimulation for $200 \mathrm{~s}$ at $150^{\circ} \mathrm{C} \mathrm{(pIR).} \mathrm{Here,}$

275 the integral 0-20 s was used for $D_{e}$ determination after subtracting the last $20 \mathrm{~s}$ as

276 background.

277 The usual rejection criteria have been applied (Wintle and Murray, 2006), and most

278 samples show good luminescence properties. While most quartz emissions are

279 dominated by the fast component (Fig. 4A), the samples from site 4216 show low OSL

280 intensity and the presence of a medium component (Fig. 4B). The latter are hence

281 considered not suitable for dating. The feldspar exhibits bright signals for both IRSL

282 (Fig. 4C) and pIR (Fig. 4D). For samples 4214.1/1 and 4214.2/1, the OSL signal is at

283 saturation, therefore only minimum ages have been determined (Fig. 4E), the feldspar

284 growth curves of the same samples, however, do not show any indication of saturation

285 (Fig. 4F). For all samples, $\mathrm{D}_{\mathrm{e}}$ distributions have been investigated (Fig. 5A, B) and

286 based on the observed spread of data, in particular the overdispersion value, either the

287 Central Age Model (CAM) or the Minimum Age Model (MAM) as described by

288 Galbraith et al. (1999) have been applied to account for the effect of differential

289 bleaching of the luminescence signal prior to deposition (Table 2).

290 The concentration of dose rate relevant elements (K, U, Th) was measured by high-

291 resolution gamma spectrometry at the University of Bern (cf. Preusser and Kasper,

292 2001). We did not observe any clear indication for radioactive disequilibrium in any of

293 the samples using the approach described by Zander et al. (2007) (Table 2). Age

294 calculations were performed with ADELE-v2015 (v.021a beta) using the dose

295 conversion factors of Guérin et al. (2011), assuming an a-value of $0.07 \pm 0.02$ for 
296 feldspar and average sediment moisture content between 0-4 \%. Cosmic dose rate was 297 calculated using present day depth after Prescott and Hutton (1994). For feldspar, an 298 internal K-content of $12.5 \pm 0.5 \%$ has been used (Huntley and Baril, 1997).

299 Considering that IRSL ages might be affected by signal instability (fading), these are 300 reported here only for completeness. While the pIR signal is expected to show less 301 fading, the use of relatively low stimulation temperatures, as done in this study to 302 minimize problems with regard to partial bleaching, may still show some instability.

303 However, we abstained from carrying out storage tests as the suitability of such

304 experiments to carry-out fading corrections is highly controversial (e.g., Wallinga et 305 al., 2007; Lowick et al., 2012; Preusser et al., 2014). Hence, in the discussion of the 306 age of sediment deposition we will only rely on OSL and pIR ages that are consistent 307 for all of our samples.

\section{Results}

\subsection{Geomorphological setting and drainage systems}

311 The present-day geological and geomorphological setting is of fundamental importance 312 to the understanding of the climate and the evolution of the drainage of Saudi Arabia 313 which is geologically divided in four distinct terrains. The Arabian Shield with its 314 crystalline rocks crops out in the western part of the Kingdom over a large area (ca. $315770^{\prime} 000 \mathrm{~km}^{2}$ ) including the orographically highest terrain of the country. It is overlain 316 by the homoclinal Phanerozoic sedimentary cover rocks, which dip slightly eastwards 317 away from the shield and form a $400 \mathrm{~km}$ wide belt. This region is bordered by the flat 318 lying sediments of the Interior Platform and the Neogene Rub' al-Khali basin (Vincent, 319 2008). The distribution of these units is mirrored by the topography, as shown in Fig. $3201 \mathrm{~A}$.

321 The geographic configuration led to the establishment of a two-part drainage network 322 separated by a water divide following the edge of the Red Sea escarpment. The first 323 part comprises the short and steep wadi systems that drain onto the Tihama coastal 324 plain. The second and major part consists of confluent wadis such as Wadi ad Dawasir 
that flow down-dip on the beds of the sedimentary cover and across the interior to the Arabian Gulf.

The Wadi ad Dawasir and Wadi as Sahba drain large catchments of $354,050 \mathrm{~km}^{2}$ and $130,145 \mathrm{~km}^{2}$, respectively, with complex distributary patterns (Fig. 1B). The Wadi ad Dawasir system comprises several major tributaries including Wadi at Tathlith that drain the crystalline terrain of the Asir Mountains. Wadi ad Dawasir breaches the Jurassic carbonates of the Tuwayq Mountains at As Sulayyil to flow in a north-easterly direction across the southern end of the Dahna desert and the Rub'al-Khali. At the pour point, it is joined from the northwest by the downstream trunk of Wadi Maqran and Wadi al Jadwal that drain the sedimentary cover. In this part of the catchment the As Sahba fan acts as barrier forcing the channels of the Dawasir system to flow eastwards (Fig. 1B, 3).

The drainage system displays a trellis pattern in the upper catchment indicative of steep slopes, and channel gradients range from 1.7 to $3.8 \mathrm{~m} \mathrm{~km}^{-1}$. This changes downstream to a parallel pattern on the plain, with the gradient of the trunk channel less than $0.7 \mathrm{~m}$ $\mathrm{km}^{-1}$ (Fig. 1). The width of the wadi narrows downstream from almost $30 \mathrm{~km}$ wide to the west of As Sulayyil to about $1.5 \mathrm{~km}$ a few kilometres downstream of this village. Further downstream the braided channel tapers out and is covered by dunes of the Dahna desert (Fig. 2A). With remote sensing techniques, however, the channel can be followed across the Dahna and Rub' al-Khali. In addition to this calculated channel, other river courses can be inferred from the flow direction in areas with intermittent dune coverage. The pattern of these inferred channels indicates large-scale movement of the river course across the fluvial plain due to avulsion. Downstream of the pour point, the main channel runs east of a ridge of Tertiary rocks along the western margin of Sabkha Matti (Fig. 1B). It is incised into older gravel deposits that can be followed along its course to the coastline (Bramkamp et al., 1961). Runoff in the Wadi ad Dawasir basin is restricted to the tributaries in the Asir where the majority of discharge occurs after storm events. However, the mean annual runoff is low with $0.95 \mathrm{~m}^{3} \mathrm{sec}^{-1}$ in Wadi at Tathlith (Vincent, 2008). Episodic floods may reach As Sulayyil, but the water dissipates within days to weeks due to very high transmission loss into the alluvium and high evaporation rate. 
356 The Wadi as Sahba catchment is drained by the larger Wadi Birk system, which 357 comprises several tributaries in the crystalline basement terrain and the smaller Wadi 358 Hanifah system that has its headwaters in the Tuwayq Mountains. They cross the 359 Tuwayq escarpment to continue downstream of their confluence as Wadi as Sahba.

360 Channel incision in Wadi Birk and Wadi Hanifah has exposed up to $6 \mathrm{~m}$ of the terrace 361 gravels. McLaren et al. (2009) dated fluvial deposits in the upper Sahba catchment to 362 ca. $54 \mathrm{ka}$ and $39 \mathrm{ka}$. A silt bed in the terrace sequence in Wadi Hanifah yielded a 363 freshwater gastropod fauna with a radiocarbon age of $8400 \pm 140{ }^{14} \mathrm{C}$ yr BP (Hötzl et 364 al., 1978b), corresponding to 9650-9020 cal. yr BP. However, the most conspicuous 365 geomorphic feature of Wadi as Sahba is its large gravel fan, which is of Late Pliocene 366 to Early Pleistocene age according to Hötzl et al. (1978a). Its distributaries entered the 367 Gulf to the east and west of the Qatar Peninsula (Fig. 3). The apex of the fan is located 368 at the end of the incised channel at the edge of the Tertiary plateau from where the 369 confined flows expanded (Bramkamp and Ramirez, 1959). The DEM of the fan shown 370 in Fig. 3 reveals the older distributary channels in inverted relief due to deflation of the 371 finer inter-channel deposits, and it also shows several channels that cross the coastal 372 plain to the coast. The large areal extent of the fan and the coarse clast size of the 373 conglomerates reveal a high erosion rate, high runoff and transport capacity during the 374 Pleistocene pluvial events. The present-day channel runs across the fan towards Al 375 Humr lake which, however, is fed by an artesian spring in the Tertiary rocks on its 376 eastern shore.

\subsection{Field observations, fauna, facies analysis, and dating results}

379 The study sites are located in the lower reaches of the Wadi ad Dawasir system and in 380 its far back hinterland in Wadi at Tathlith (Fig. 1B). The measured and dated sections 381 from the unconfined floodplain of Wadi ad Dawasir (Fig. 6) are all situated in 382 interdunal areas where deflation has exposed a dense braided channel network with 383 main and auxiliary channels. These channels, which drained the floodplain visualized 384 by satellite imagery have a low sinuosity and a width up to $50 \mathrm{~m}$ (Fig. 7A). As they 385 lack topographic expression, however, they can be identified in the field only by thin 386 veneers of pebbles mixed with coarse sand and aquatic fossils (Fig. 6). The sub-angular 387 to sub-rounded clasts are mostly of igneous and metamorphic origin with abundant 
quartzite and vein quartz of maximum sizes ranging from less than $1 \mathrm{~cm}$ up to $10 \mathrm{~cm}$ (Fig. 7B). The outcrop at site 4213.2 appears as a narrow light grey band stretching a few tens of meters across the barren, tan sand-covered plain (Fig. 7C). It is littered with Melanoides tuberculata and Unio tigridis as well as Corbicula fluminalis and Radix natalensis. Many of the specimens of $U$. tigridis are preserved with both valves, resting in-situ embedded in the calcareous sand (Fig. 7B). This indicates that the shells were not transported by the river but remained in the original position after death.

In sections 4213.1 and 4213.3 the gravel lag rests on unfossiliferous quartz sand, whereas in sections 4213.2, 4214.1 and 4214.2 it overlies fossiliferous calcareous sand, clayey sand or marl (Fig. 6). The basal unit consists of structureless or faintly laminated bimodal coarse quartz sand. The grains are very well rounded and most of them show a frosted surface. Cailleux (1952) described this grain type as RM (French 'Ronds-Mats' = round and dull), and he attributed this appearance to cavities covering the surface. According to SEM imaging by Krinsley and Doornkamp (1973), these dish-like concavities are formed by grain collisions during strong winds. The presence of grains with this morphology, however, does not necessarily imply that the sands in the studied sections represent aeolian deposits. Sequence 4213.3, recorded in a trench excavated with a bulldozer across a fluvial channel, bottomed in hard unfossiliferous marl, probably of Neogene age. The channel is filled with well-rounded quartz sand that had been reworked by Wadi ad Dawasir along its course across the Dahna and Rub' al-Khali deserts. In contrast, the basal sand unit of none of the other sections mentioned above was bottomed. These sands lack facies with diagnostic sedimentary structures other than faint lamination. According to OSL/pIR dating, the sands in sections 4213 are of Holocene age (dated between $7900 \pm 600$ a and $3700 \pm 300$ a by luminescence, with discrepancies compared to radiocarbon dated discussed below), whereas 4214.1 and 4214.2 date to the early Late Pleistocene (pIR ages of $90 \pm 6 \mathrm{ka}$ and $109 \pm 11 \mathrm{ka}$, OSL ages being minimum estimates due to signal saturation). We speculate that sands of Holocene age are fluvial and those of Pleistocene age are aeolian deposits (Fig. 6). This interpretation is supported by the channel geometry at site 4213.3, the lighter colour of the Holocene sands and a palaeosol with a sharp erosional surface that separates the Pleistocene basal sand from the overlying Holocene 
419 fluvio-lacustrine marl in section 4214.2 indicating a period of non-sedimentation. This site is located on the floodplain and the section was measured in a hand-dug pit.

421 The beds of section 4214.3 occur as a low mesa remnant with a relief of about $2 \mathrm{~m}$ 422 located about $200 \mathrm{~m}$ eastwards of site 4214.2. The sequence is of Holocene age according to OSL/pIRL $(6100 \pm 300 / 5600 \pm 300$ a) and radiocarbon $(8400-8700 \mathrm{cal}$. yr

424 BP) dating. It consists of alternating 5 to $10 \mathrm{~cm}$-thick beds of fossiliferous calcareous sands and marl with a $40 \mathrm{~cm}$-thick marl at the top (Figs 6, 7D). These beds contain a rich freshwater malacofauna with Unio tigridis, Corbicula fluminalis, Melanoides tuberculata, Radix natalensis and Bulinus sp., and rests on loose sand of Holocene age.

428 This consists of very well rounded quartz grains with the frosted surface texture 429 characteristic of aeolian abrasion.

430 The freshwater malacofauna of the lower Dawasir basin is congruent with the findings 431 of Hötzl et al. (1978b), with the only exception that these authors did not find any 432 freshwater bivalves, while in our assemblage the pulmonate Biomphalaria pfeifferi is 433 missing.

434 The ostracod fauna found in four out of six sections of the lower Wadi ad Dawasir 435 basin (Fig. 6) consists of eight species, four of which were identified to genus level. 436 Abundance varies from very low (four valves in 4213.2/2) to high (161 valves in 437 4214.3/2), whereas other samples yield moderate abundances (33-45 valves). The most 438 prominent species in four out of five samples is Cyprideis torosa which mainly occurs 439 in marine brackish waters down to a water depth of $30 \mathrm{~m}$, but also occurs in freshwater 440 (McClure and Swain, 1980; Meisch, 2000). The second most abundant species is 441 Pseudocandona marchica, which inhabits permanent and temporary water bodies, and 442 the littoral zone of lakes, to a depth of $30 \mathrm{~m}$ (McClure and Swain, 1980; Meisch, 443 2000). The following species are present in low abundance: Hemicypris sp., Ilyocypris 444 sp., Cypretta sp., Cyprinotus, Cypridopsis vidua and Cypris pubera. These species 445 thrive in a broad variety of aquatic environments from small and shallow permanent 446 ponds to creeks. The presence of Cypris pubera indicates a salinity of $<4 \%$ (Meisch, 447 2000).

448 Wadi at Tathlith carved its valley in the crystalline rocks of the Arabian shield. The up 449 to $200 \mathrm{~m}$-wide floodplain is occupied by coarse grained gravel platforms and sand bars 
450 that are moved as bedload during ephemeral floods. Older deposits, possibly of

451 Pleistocene age (Whitney, 1983), are exposed where the river has incised into the

452 lowest gravel terrace which is ca. $6 \mathrm{~m}$ above the wadi's floodplain. Two outcrop

453 sections were measured on the eastern bank of the wadi (Fig. 8). Section 4216.2

454 consists of weakly cemented sandy polymict gravels showing poor sorting,

455 stratification and layers with imbricated angular to sub-rounded clasts up to $10 \mathrm{~cm}$ in

456 size (Fig. 8; Whitney 1983 Fig. 14). The pIR age of $29.8 \pm 1.6$ ka dates the section to

457 late MIS 3. About $2.5 \mathrm{~km}$ downstream, section 4216.1 was logged in the same terrace

458 but in sandy facies with rare gravel pockets. The sequence consists of three units

459 separated by dark palaeosols with iron stained grains (Figs. 7E, 8). These must record

460 hiatuses in sedimentation, as palaeosol development requires landscape stability with

461 neither deposition nor erosion. The sample that was taken at the base of the middle unit

462 revealed an pIR age of $7100 \pm 700$ a. Due to ponding behind a constriction of the wadi

463 about $17 \mathrm{~km}$ upstream of site 4216.2, extensive fine-grained alluvium was deposited

464 (Fig. 7F). It is characterized by tan laminated silts, cross-bedded fine-grained sands and

465 occasional gravel interbeds. Radiocarbon dating of charcoal from the top of the

466 sequence reported originally by Whitney (1983) gave ages of $6120 \pm 110{ }^{14} \mathrm{C}$ yr BP

467 (7260-6740 cal. yr BP) and $5700 \pm 250{ }^{14} \mathrm{C}$ yr BP (7160-5990 cal. yr BP). The fine-

468 grained alluvium contrasts sharply with the older coarse-grained sediments indicating a

469 decrease of flow intensity at the end of the Holocene pluvial. This change towards

470 increased aridity is further supported by the occurrence of abundant displacive

471 lenticular as well as swallow-tailed twinned gypsum crystals in the uppermost silts

472 indicating an evaporitic environment.

\section{4. Discussion}

475 4.1. Timing of fluvial activity

476 Considering the age of fluvial deposition, there is an obvious discrepancy between 477 radiocarbon (of shell material) and luminescence ages (Fig. 6, 9). For the four sites 478 where both methods have been applied, the radiocarbon ages are systematically older, 479 though these have been measured for shells collected above the horizons dated by 480 luminescence. All radiocarbon ages are between 7 and $9 \mathrm{ka}$, but the luminescence ages 481 are mainly several thousand years younger (up to $4 \mathrm{ka}$ ). Age underestimation of 
482 luminescence ages could be caused by signal instability but the OSL signal of the 483 samples is clearly dominated by the fast component that is stable over millions of years 484 (e.g., Preusser et al., 2009). Furthermore, the OSL ages agree very well with the pIR ages that have different physical properties. There is also no indication for radioactive disequilibrium in the samples that could have led to miscalculation of dose rate.

487 On the other hand, radiocarbon samples could have been re-worked, but this appears unlikely as the material is well preserved and embedded. Rather, shell material could be affected by the hardwater effect, i.e. an up-take of dissolved ancient carbonates. In this case the ${ }^{14} \mathrm{C}$ level is lower than the atmosphere and the basic assumption of radiocarbon dating that a sample incorporates carbon in equilibrium with the atmosphere is no longer fulfilled. A hardwater effect between 0 and almost 6000 years is possible in freshwater systems (Clark and Fritz, 1997; Philippsen, 2013). This effect

494 is well known from several studies in Arabia, with the radiocarbon ages from shell carbonate being a few hundred to 1500 years older than the age of associated organic material (Davies, 2006; Rosenberg et al., 2011b; Dinies et al., 2015). However, the pIR/OSL ages for site 4213.3 are almost $4.0 \mathrm{ka}$ older than its radiocarbon age of about 7300 cal. yr BP (Unio tigridis). To achieve the almost double as old radiocarbon age, carbon taken up by the mussel should be composed of $\sim 1 / 3$ fossil and $\sim 2 / 3$ contemporary material, which appears quite high. Nevertheless, the samples under consideration here are from the context of a river system that crosses through areas with abundant limestone that will be dissolved in the water. Hence, the hardwater effect should indeed be much higher than in samples from Mundafan, where noncarbonate bearing basement and volcanic rocks are outcropping. Interestingly, we found almost identical ages for U. tigridis and $M$. tuberculata at several sites, which is unexpected as their habitats and their diets are different and this should be reflected by differences in the hardwater effect.

508 In summary, there is no unequivocal explanation for the observed offset between pIR 509 and OSL ages on the one hand, and radiocarbon ages on the other hand. Despite this, a 510 certain offset caused by hardwater uptake must be expected from the environmental 511 setting (creatures living in and feeding from resources associated to carbonate-rich 512 water). Hence, we are relying on the luminescence ages in the later chronological 513 interpretation. 


\subsection{Palaeoenvironmental inferences}

516 The narrow width of the channels in the lower reach of the Wadi ad Dawasir system in

517 combination with a gravel lag consisting of well-rounded pebble-sized clasts indicate a

518 rather sluggish regime of the Holocene rivers. This is supported by the preservation of

$519 U$. tigridis with both valves intact. However, no conclusive inference is possible with

520 regards to channel depth as sequence thickness has been reduced by strong aeolian

521 deflation in this area. Inverted fluvial channels (Fig. 2D) are further evidence of this

522 process. The section at site 4214.3 composed of alternating 5 to $10 \mathrm{~cm}$-thick

523 fossiliferous sand and marl beds with planar contacts is interpreted as flood deposits

524 and low-energy homogeneous fines, respectively deposited in a shallow lake.

525 The fauna comprising gastropods, bivalves, ostracodes and rare charophytes is

526 identical in both the fluvial and lacustrine deposits. The composition of the fossil

527 freshwater malacofauna is typical for the area and similar to present day populations

528 (Neubert, 1998; Neubert et al., 2015). All species recorded are extant besides the large

529 freshwater mussel $U$. tigridis. Until now, this species has not been recorded from the

530 Arabian Peninsula; however, our results demonstrate that its extinction was a quite

531 recent event. Remarkably, this species is not recorded from the nearby oasis Al Hasa,

532 even though this oasis has an enormous permanent freshwater supply. This might be

533 due to the fact that this oasis belongs to a separate drainage system receiving its water

534 from groundwater wells, and it thus was not connected to the Dawasir or the Sahba

535 system.

536 Today, U. tigridis lives in the lentic, i.e. relatively still water, shore area of large to

537 medium-sized rivers and larger lakes in the Euphrates-Tigris basin in Turkey, Syria,

538 Iraq and probably Iran (Al-Bassam and Hassan, 2006; Lopes-Lima and Seddon, 2014).

539 These bivalves need freshwater fish species as intermediate hosts for their larvae, and

540 thus require a stable, perennial habitat with relatively large water bodies (Matter et al.,

541 2015). In the investigated area, these mussels have been the most abundant fossils

542 representing a large and well-established population. From resettlement experiments in

543 Europe we know that Unio species are extremely sensitive concerning the quality of

544 their habitats. It may take 10-20 years of insertion of infected fish specimens until a 
545 first population is established. After that, hatchlings need between 4-10 years until

546 reaching maturity. This demonstrates that habitats need to be stable for 30 years at least

547 to support a single generation of mussels. We frequently observed mussels of differing

548 sizes in our fossiliferous layers, which we interpret as several subsequent generations

549 of mussels, and thus as evidence of stable habitat conditions in the order of magnitude

550 of one to several centuries. A short-termed fluctuation in habitat conditions such as in

551 an ephemeral flow regime with subsequent re-settlement of a rich mussel fauna is very

552 unlikely. The remaining species can be considered more euryoecious, i.e. they are able

553 to survive in short-lived habitat and re-colonise it after desiccation given there are

554 surviving populations in the surroundings. Only M. tuberculata, which has a

555 parthenogenetic mode of reproduction, is able to colonise even small (and also

556 brackish) water bodies from a single specimen. For this reason it can be found as a

557 tramp-species in all tropical and subtropical biomes. The palaeoecological information

558 of the ostracod fauna is less conclusive because all of the species are typical of a

559 variety of permanent and temporary aquatic habitats and most of them tolerate

560 moderate to high salinities. The occurrence of Cyprideis torosa, however, indicates

561 warm, shallow and permanent water bodies as its eggs cannot withstand desiccation

562 (Anadón et el., 1986; Pint et al., 2012). It develops characteristic nodes in low-salinity

563 waters with $\mathrm{Ca}^{2+}$ deficiency (Frenzel et al., 2012). The Dawasir samples yielded

564 smooth shells, which may only suggest saline conditions rather than freshwater as

565 indicated by U. tigridis. However, according to Frenzel et al. (2012), the use of nodes

566 as a proxy for palaeowater chemistry requires further study of the relationships of

567 water chemistry and shell morphology; they find that both ionic composition and

568 salinity may influence morphological response (Pint et al., 2012). Therefore, the

569 morphology of C. torosa should be used with caution as a palaeosalinity indicator of

570 athalassic waters (Pint et al., 2012).

571 The geomorphologic, sedimentological and biological observations suggest that the

572 lower reach of the Dawasir system in Holocene times was a fluvial plain with several

573 river channels and floodplain lakes. The alternation of sand and marl beds in the

574 lacustrine sequence indicates flooding of the lake from overtopping river channels as a

575 result of fluctuating discharge. The re-interpretation by Enzel et al. (2015) of Holocene

576 palaeolakes in Arabia as marshes neglects the biological evidence that unionid mussels 
and Cyprideis torosa need permanent water and are unable to survive in a marsh environment.

The presence of flowing rivers and permanent lakes in Wadi ad Dawasir during the Holocene wet period raises the question as to the source of the rainfall. Many studies carried out during the past decade associated the observed environmental fluctuations with a shift in the latitudinal position of the ITCZ and associated monsoonal rainfall belt, but there is surprisingly little information on its position across the Peninsula at different times. Increased precipitation during the Early to Middle Holocene appears to be restricted to North Arabia, the south-eastern, southern and western margins of the Peninsula from the Emirates to the Yemeni Highlands, and the Asir Mountains. Central Arabia and the Rub' al-Khali seem to have remained arid, lacking widespread Holocene lake deposits. Thus, the perennial Dawasir river represents a trans-Arabian lifeline across a hostile desert environment during the Holocene. This is further supported by the occurrence of Neolithic stone tools along the wadi course indicating that is was a favourable habitat for humans (Crassard et al., 2013). This palaeohydrological situation implies that the main source area of water feeding Wadi ad Dawasir in the Holocene must have been the Asir Mountains that received high amounts of rainfall due to the eastern movement of the African Summer Monsoon. Increased precipitation in this area is documented by the accumulation of river sediments, for example, in Wadi Tathlith dated to 7.1 ka and 6.1-5.7 ka and a Holocene lake at Mundafan fed by river channels draining these mountains (Rosenberg et al., 2011b). Radiocarbon dating of phytoclasts (plant particles) revealed that Lake Mundafan existed from 9600 to 7900 cal. yr BP, whereas the activity of Wadi ad Dawasir is documented in this work from ca. 7.9 to $4.0 \mathrm{ka}$ according to luminescence dating. Fluvial accumulation at 5.9-5.3 ka, 4.8-4.5 ka and 4.0-2.7 ka in southern Yemen reveals that the rainfall regime in this area did not end with the so-called 'classic' Holocene wet period though the last lake dated to 7.3 ka (Lézine et al., 2010; Berger et al., 2012). This decrease in precipitation is in accord with the Qunf cave stalagmite record, which shows a concomitant decrease of $\delta^{18} \mathrm{O}$ after 7 ka to modern values at 2.6 ka (Fleitmann et al., 2007). 


\section{Conclusions}

609 Remote sensing methods allowed fluvial channels of the Sahba and Dawasir systems to

610 be mapped from the Asir mountainous watershed across the partially sand covered

611 interior of the Arabian Peninsula to the Arabian Gulf, facilitating the analysis of the 612 palaeoenvironmental archives deposited during the Holocene wet phase.

613 Sedimentological and faunal analyses reveal the presence of a stable habitat with

614 perennial rivers and a permanent freshwater lake in the distal reach of the Dawasir

615 system lasting up to several hundred years, which are synchronous with fluvial

616 accumulations in the headwaters of its major tributary Wadi Tathlith. As there are no

617 indications of Holocene lakes in most of the Rub' al-Khali it appears that the Dawasir,

618 Sahba and possibly other trans-Arabian rivers were fed by precipitation in the Asir

619 Mountains as a result of an intensified African summer monsoon. Hence, the general

620 climatic setting was different from today, likely with higher summer rainfall in the Asir

621 Mountains compared to the present, possibly accentuated by topographic effects.

622 However, rainfall was likely not ubiquitous across the peninsula. The direct influence

623 of the monsoonal rainfall belt was apparently limited to the south-eastern, southern and

624 western margin as well as the northern part of the Arabian Peninsula, but did not reach

625 into its interior. Increased runoff during the Holocene wet phase led to a re-activation

626 of the Dawasir river, largely following its Late Pleistocene course and eroding into its

627 previously deposited gravels and the sands of the Rub' al-Khali. The

628 palaeoenvironmental reconstruction suggests a narrow, trans-Arabian green freshwater

629 corridor as a result of presumably seasonal flooding similar to that of the River Nile.

630 The permanent availability of water and subsistence for wildlife provided a favourable

631 environment for human occupation as documented by Neolithic stone tools found

632 along the length of Wadi ad Dawasir.

\section{Acknowledgements}

635 We thank Dr. Zohair A. Nawab, President of the Saudi Geological Survey (SGS), Dr.

636 Abdullah M. Al-Attas, Assistant President for Technical Affairs and Saleh Al-Ghamdi,

637 Director of Desert Studies of SGS for their interest and support. We thank Siddiq

638 Habibullah and Abdulaziz Al-Solami for assistance in the field, and Dr. Urs 
639 Eggenberger for the XRD analysis of the shell material, and Cornelia Fischer for

640

641

642

643

644

645

646

647

648

649

650

651

652

653

654

655

656

657

658

659

660

661

662

663

664

665

666

667

668

assistance in ostracod analysis. Prof. Dominik Fleitmann kindly provided the isotope data used in Fig. 9. Dr. Laine Clark-Balzan is thanked for her comments on a previous version of the manuscript. Prof. Martin Williams, two anonymous reviewers and the editor Andrew Plater are thanked for their useful and constructive comments.

\section{References}

Abrams, M., Bailey, B., Tsu, H., Hato, M., 2010. The ASTER global DEM.

Photogrammetric Engineering and Remote Sensing 76, 344-348.

Abrams, M., Tsu, H., Hulley, G., Iwao, K., Pieri, D., Cudahy, T., Kargel, J., 2015. The Advanced Spaceborne Thermal Emission and Reflection Radiometer (ASTER) after fifteen years: Review of global products. International Journal of Applied Earth Observation and Geoinformation 38, 292-301.

Al-Bassam, K.S., Hassan, K.M., 2006. Distribution and ecology of recent molluscs in the Euphrates river - Iraq. Iraqi Bulletin of Geology and Mining 2, 57-66.

Almazroui, M., Islam, M.N., Athar, H., Jones, P.D., Rahman, M.A., 2012. Recent climate change in the Arabian Peninsula: annual rainfall and temperature analysis of Saudi Arabia for 1978-2009. International Journal of Climatology 32, 953-966.

Anadón, P., De Dekker, P., Julià, R., 1986. The Pleistocene lake deposits of the NE Baza Basin (Spain): salinity variations and ostracod succession. Hydrobiologia 143, 199-208.

Anton, D., 1984. Aspects of geomorphological evolution; Paleosols and dunes in Saudi Arabia. In: Jado, A.R., Zötl, J.G. (eds.): Quaternary Period in Saudi Arabia 2, 275296.

Berger, J.-F., Bravard, J.-P., Purdue, L., Benoist, A., Mouton, M., Braemer, F., 2012. Rivers of the Hadramawt watershed (Yemen) during the Holocene: Clues of late functioning. Quaternary International 266, 142-161.

Blechschmidt, I., Matter, A., Preusser, F., Rieke-Zapp, D., 2009. Monsoon triggered formation of Quaternary alluvial megafans in the interior of Oman. Geomorphology $110,128-137$. 
Bramkamp, R.A., Ramirez, L.F., 1959. Geology of the Northwestern Rub' al-Khali Quadrangle. Kingdom of Saudi Arabia, USGS, Misc. Geol. Investigations Map I213A, $1: 500,000$. Washington.

\section{Bramkamp, R.A., Ramirez, L.F., 1961. Geologic Map of the Central Persian Gulf} Quadrangle. Kingdom of Saudi Arabia, USGS, Misc. Geol. Investigations Map I214A, $1: 500,000$. Washington.

Bosmans, J.H.C., Drijfhout, S.S., Tuenter, E., Hilgen, F.J., Lourens, L.J., 2014.

Response of the North African summer monsoon to precession and obliquity forcings in the EC-Earth GCM. Climate Dynamics 44, 279-297.

Breeze, P., Drake N.A., Groucutt, H.S., Parton, A., Jennings, R.P., White, T.S., ClarkBalzan, L., Shipton, C., Scerri, E.M.L., Stimpson, C.M., Crassard, R., Hilbert, Y., Alsharekh, A., Al-Omari, A., Petraglia, M.D., 2015. Remote sensing and GIS techniques for reconstructing Arabian palaeohydrology and identifying archaeological sites. Quaternary International 382, 98-119.

Brown, G.F., 1960. Geomorphology of central and western Saudi Arabia. $21^{\text {st }}$ International Geological Congress 150-159.

Brown, G.F., Schmidt, D.L., Huffman, Jr., A.C., 1989. Geology of the Arabian Peninsula - Shield Area of Western Saudi Arabia. U.S. Geological Survey Professional Paper 560A, 199pp.

Burns, S.J., Fleitmann, D., Matter, A., Neff, U., Mangini, A., 2001. Speleothem evidence from Oman for continental pluvial events during interglacial periods. Geology 29, 623-626.

Cailleux, A., 1952. Morphoskopische Analyse der Geschiebe und Sandkörner und ihre Bedeutung für die Paläoklimatologie. Geologische Rundschau 40, 11-19.

Camp, V.E., Roobol, M.J., 1989. The Arabian continental alkali basalt province: Part 1. Evolution of Harrat Rahat, Kingdom of Saudi Arabia. Bulletin of the Geological Society of America 101, 71-95.

Camp, V.E., Roobol, M.J., 1991. Geologic map of the Cenozoic lava field of Harrat 697 Rahat, Kingdom of Saudi Arabia. Saudi Arabian Directorate of Mineral Resources 69 Geosciences Map GM-123, scale $1: 250,000$, with text 37 pp.

699 Catlett, G.A., 2014. Pluvial deposits in Mudawwara, Jordan and their implications for 00 Mediterranean and monsoonal precipitation in the Levant. M.Sc. Thesis, Miami University, Oxford, Ohio, 32 pp. 
Clark, I.D., Fritz, P., 1967. Environmental Isotopes in Hydrogeology. New York, Boca Raton, Lewis Publishers, CRC Press LLC, 352 pp.

Crassard, R., Petraglia, M.D., Drake, N.A., Breeze, P., Gratuze, B., Alsharekh, A., Arbach, M., Groucutt, H.S., Khalidi, L., Michelsen, N., Robin, C.J., Schiettecatte, J., 2013. Middle Palaeolithic and Neolithic occupations around Mundafan palaeolake, Saudi Arabia: Implications for climate change and human dispersal. PLOS One 8, e69665.

Davies, C.P., 2006. Holocene paleoclimates of southern Arabia from lacustrine deposits of the Dhamar highlands, Yemen. Quaternary Research 66, 454-464.

Dinies, M., Plessen, B., Neef, R., Kürschner, H., 2015. When the desert was green: Grassland expansion during the early Holocene in northwestern Arabia. Quaternary International 382, 293-302.

Edgell, H.S., 1990. Evolution of the Rub' al Khali desert. Journal of King Abdulaziz University: Earth Sciences, vol. 3, Special Issue, $1^{\text {st }}$ Saudi Symposium on Earth Sciences 1989, 81-93, Jeddah.

Edgell, H.S., 2006. Arabian Deserts. Nature, Origin and Evolution. Springer,

.

Engel, M., Brückner, H., Pint, A., Wellbrock, K., Ginau, A., Voss, P., Grottker, M., Klasen, N., Frenzel, P., 2012. The early Holocene humid period in NW Saudi Arabia - Sediments, microfossils and palaeo-hydrological modelling. Quaternary International 266, 131-141.

Enzel, Y., Kushnir, Y., Quade, J., 2015. The middle Holocene climatic records from Arabia: Reassessing lacustrine environments, shift of ITCZ in Arabian Sea, and impacts of the southwest Indian and African monsoon. Global and Planetary Change 129, 69-91.

Farr, T.G., Kobrick, M., 2000. Shuttle radar topography mission produces a wealth of data. Eos, Transactions American Geophysical Union 81, 583.

Farr, T.G., Rosen, P.A., Caro, E., Crippen, R., Duren, R., Hensley, S., Kobrick, M.,

731 Werner, M., Oskin, M., Burbank, D., Alsdorf, D., 2007. The Shuttle Radar Topography Mission. Reviews of Geophysics 45, RG2004. 
733 Fleitmann, D., Burns, S.J., Neff, U., Mangini, A., Matter, A., 2003a. Changing

734 moisture sources over the last 330,000 years in Northern Oman from fluid-inclusion evidence in speleothems. Quaternary Research 60, 223-232.

736 Fleitmann, D., Burns, S.J., Mudelsee, M., Neff, U., Kramers, J., Mangini, A., Matter, 737 A., 2003b. Holocene forcing of the Indian monsoon recorded in a stalagmite from $738 \quad$ Southern Oman. Science 300, 1737-1739.

739 Fleitmann, D., Matter, A., Pint, J., Al-Shanti, M.A., 2004. The speleothem record of $740 \quad$ climate change in Saudi Arabia. Open-File Report, SGS-OF-2004-8. Saudi 741 Geological Survey. 40 pp.

742 Fleitmann, D., Burns, S.J., Neff, U., Mudelsee, M., Mangini, A., Kramers, J., Matter, 743 A., 2005. Holocene records of rainfall variation and associated ITCZ migration from 744 stalagmites from northern and southern Oman. In: Diaz, H.F., Bradley, R.S. (eds.), 745 The Hadley Cell Circulation: Present, past and future, 259-287. Kluwer Academic 746 Publishers. Dordrecht, The Netherlands.

747 Fleitmann, D., Burns, S.J., Mangini, A., Mudelsee, M., Kramers, J., Villa, I., Neff, U., 748 Al-Subbary, A.A., Buettner, A., Hippler, D., Matter, A., 2007. Holocene ITCZ and 749 Indian monsoon dynamics recorded in stalagmites from Oman and Yemen (Socotra). 750 Quaternary Science Reviews 26, 170-188.

751 Fleitmann, D., Burns, S.J., Pekala, M., Mangini, A., Al-Subbary, A., Al-Aowah, M., 752 Kramers, J., Matter, A., 2011. Holocene and Pleistocene pluvial periods in Yemen, 753 southern Arabia. Quaternary Science Reviews 30, 783-787.

754 Frenzel, P., Schulze, I., Pint, A., 2012. Noding of Cyprideis torosa valves (Ostracoda) $755-$ a proxy for salinity? New data from field observations and a long-term microcosm 756 experiment. International Review of Hydrobiology 97, 314-329.

757 Galbraith, R.F., Roberts, R.G., Laslett, G.M., Yoshida, H., Olley, J.M., 1999. Optical 758 dating of single and multiple grains of quartz from Jinmium rock shelter, northern 759 Australia, part 1, Experimental design and statistical models. Archaeometry 41, 339760364.

761 Ginau, A., Engel, M., Brückner, H., 2012. Holocene chemical precipitates in the 762 continental sabkha of Tayma (NW Saudi Arabia). Journal of Arid Environments 84, $763 \quad 26-37$. 
764 Goward, S.N., Masek, J.G., Williams, D.L., Irons, J.R., Thompson, R.J., 2001. The 765 Landsat 7 mission. Remote Sensing of Environment 78, 3-12.

766 Goudie, A.S., Colls, A., Stokes, S., Parker, A., White, K., Al-Farraj, A., 2000. Latest

767 Pleistocene and Holocene dune construction at the north-eastern edge of the Rub' al 768 Khali, United Arab Emirates. Sedimentology 47, 1011-1021.

769 Groucutt, H.S., White, T.S., Clark-Balzan, L., Parton, A., Crassard, R., Shipton, C., 770 Jennings, R.P., Parkar, A.G., Breeze, P.S., Scerri, E.M.L., Alsharekh, A., Petraglia, 771 M.D., 2015. Human occupation of the Arabian Empty Quarter during MIS 5:

772 evidence from Mundafan Al-Bahayrah, Saudi Arabia. Quaternary Science Reviews $773 \quad 119,116-135$.

774 Guérin, G., Mercier, N., Adamiec, G., 2011. Dose-rate conversion factors: update. 775 Ancient TL 29, 5-8.

776 Herold, M., Lohmann, G., 2009. Eemian tropical and subtropical African moisture 777 transport: an isotope modelling study. Climate Dynamics 33, 1075-1088.

778 Hilbert, Y.H., White, T., Parton, A., Clark-Balzan, L., Crassard, R., Groucutt, H.S., 779 Jennings, R.P., Breeze, P., Parker, A., Shipton, C., Al-Omari, A., Alsharekh, A., 780 Petraglia, M.D., 2014. Epipalaeolithic occupation and palaeoenvironments of the 781 southern Nefud desert, Saudi Arabia, during terminal Pleistocene and Early 782 Holocene. Journal of Archaeological Science 50, 460-474.

783 Hoffmann, G., Rupprechter, M., Rahn, M., Preusser, F., 2015. Fluvio-lacustrine 784 deposits reveal precipitation pattern in SE Arabia during early MIS 3. Quaternary 785 International 382, 145-153.

786 Holm, D.A., 1960. Desert geomorphology in the Arabian Peninsula. Science 132, 787 1369-1379.

788 Hötzl, H., Maurin, V., Zötl, J.G., 1978a. Geologic history of the Al Hasa area since the 789 Pliocene. In: Al-Sayari, S.S., Zötl, J.G. (eds.): Quaternary Period in Saudi Arabia, 790 58-77. Wien, Springer-Verlag.

791 Hötzl, H., Felber, H., Maurin, V., Zötl, J.G., 1978b. Accumulation terraces of Wadi 792 Hanifa and Wadi Al Luhy. In: Al-Sayari, S.S., Zötl, J.G. (eds.): Quaternary Period in 793 Saudi Arabia, 202-209. Wien, Springer-Verlag.

794 Huntley, D.J., Baril, M.R., 1997. The K content of the K-feldspars being measured in 795 optical dating or in thermoluminescence dating. Ancient TL 15, 11-14. 
Jennings, R.P., Singarayer, J., Stone, E.J., Krebs-Kanzow, U., Khon, V., Nisancioglu, K.H., Pfeiffer, M., Zhang, X., Parker, A., Parton, A., Groucutt, H.S., White, T.S., Drake, N.A., Petraglia, M.D., 2015. The greening of Arabia: Multiple opportunities for human occupation of the Arabian Peninsula during the Late Pleistocene inferred from an ensemble of climate model simulations. Quaternary International 382, 181199.

Jenson, S. K., Domingue, J. O., 1988. Extracting topographic structure from digital elevation data for Geographic Information System Analysis. Photogrammetric Engineering and Remote Sensing 54, 1593-1600.

Juyal, N., Singhvi, A.K., Glennie, K.W., 1998. Chronology and palaeoenvironmental significance of Quaternary desert sediment in southeastern Arabia. In: Alsharan, A.S., Glennie, K.W., Whittle, G.L., Kendall, C.G.St.C. (eds.), Quaternary Deserts and Climate Change, 315-325, Rotterdam, Balkema.

Krinsley, D.H., Doornkamp, J.C., 1973. Atlas of quartz sand surface textures. Cambridge, University Press, 91pp.

Lézine, A.-M., Saliège, J.-F., Robert, C., Wertz, F., Inizan, M.-L., 1998. Holocene lakes from Ramlat as-Sab'atayn (Yemen) illustrate the impact of monsoon activity in southern Arabia. Quaternary Research 50, 290-299.

Lézine, A.-M., Robert, C., Cleuziou, S., Inizan, M.-L., Braemer, F., Saliège, J.-F., Sylvestre, F., Tiercelin, J.-J., Crassard, R., Méry, S., Carpentier, V., Steimer-Herbst, T., 2010. Climate change and human occupation in the Southern Arabian lowlands during the last deglaciation and the Holocene. Global and Planetary Change 72, 412428.

Lopes-Lima, M., Seddon, M.B., 2014. Unio tigridis. The IUCN red list of threatened species, version 2015.2. www.iucnredlist.org. Downloaded on 28 August 2015.

Lowick, S.E., Trauerstein, M., Preusser, F. 2012. Testing the application of post IRIRSL dating to fine grain waterlain sediments. Quaternary Geochronology 8, 33-40. Matter, A., Neubert, E., Preusser, F., Rosenberg, T.M., Al-Wagdani, K., 2015. Palaeoenvironmental implications derived from lake and sabkha deposits of the southern Rub' al-Khali, Saudi Arabia and Oman. Quaternary International 382, 120-131. McClure, H.A., 1976. Radiocarbon chronology of Late Quaternary lakes in the Arabian desert. Nature 263, 755-756. 
McClure H. A., 1984. Late Quaternary palaeoenvironments of the Rub'al Khali. PhD thesis, London, University of Central London (unpublished), 245pp.

McClure, H.A., Swain, F.M., 1980. Fresh-water and brackish-water fossil Quaternary Ostracoda from the Rub' al Khali (“Empty Quarter”), Saudi Arabia. Actes du VI Colloque Africain de Micropaléontologie, Tunis, 1974. Annales des Mines et de la Géologie, Tunis, 28, tome III, 427-441.

McLaren, S.J., Al-Juaidi, F., Bateman, M.D., Millington, A.C., 2009. First evidence for episodic flooding in the arid interior of central Saudi Arabia over the last $60 \mathrm{ka}$. Journal of Quaternary Science 24, 198-207.

Meisch, C., 2000. Freshwater ostracoda of western and central Europe. Süsswasserfauna von Mitteleuropa, vol. 8 Crustacea. Schwoerbel, J., Zwick, P. (eds.). Spektrum Akademischer Verlag, 522pp.

Murray, A.S., Wintle, A.G., 2000. Luminescence dating of quartz using an improved single-aliquot regenerative-dose protocol. Radiation Measurements 32, 57-73.

Neff, U., Burns, S.J., Mangini, A., Mudelsee, M., Fleitmann, D., Matter, A., 2001. Strong coherence between solar variability and the monsoon between 9 and $6 \mathrm{kyr}$ ago. Nature 411, 290-293.

Neubert, E., 1998. Annotated checklist of the terrestrial and freshwater Molluscs of the Arabian Peninsula. Fauna of Arabia, 17, 333-461. Basel/Riyadh.

Neubert, E., Amr, Z., van Damme, D., 2015. Chapter 4: The status and distribution of freshwater molluscs in the Arabian Peninsula. In: Garcìa, N., Harrison, I., Cox, N., Tognelli, M.F. (compilers): The status and distribution of the freshwater biodiversity in the Arabian Peninsula: 30-38, Appendix 2. Gland, Switzerland, Cambridge, UK., Arlington, USA:IUCN.

Parker, A.G., Eckersley, L., Smith, M.M., Goudie, A.S., Stokes, S., Ward, S., White, K., Hodson, M.J., 2004. Holocene vegetation dynamics in the north-eastern Rub' alKhali desert, Arabian Peninsula: a phytolith, pollen and carbon isotope study. Journal of Quaternary Science 19, 665-676.

Parker, A.G., Goudie, A.S., Stokes, S., White, K., Hodson, M.J., Manning, M., Kennet, D., 2006. A record of Holocene climate change from lake geochemical analyses in southeastern Arabia. Quaternary Research 66, 465-476. 
859

860

861

862

863

864

865

866

867

868

869

870

871

872

873

874

875

876

877

878

879

880

881

882

883

884

885

886

887

888

889

Parton, A., Farrant, A.R., Leng, M.J., Telfer, M.W., Groucutt, H.S., Petraglia, M.D., Parker, A., 2015. Alluvial fan records from southeast Arabia reveal multiple windows for human dispersal. Geology 43, 295-298.

Petit-Maire, N., Carbonel, P., Reyss, J.L., Sanlaville, P., Abed, A., Bourrouilh, R., Fontugne, M., Yasin, S., 2010. A vast palaeolake in Southern Jordan (29 N). Global and Planetary Change 72, 368-373.

Petraglia, M.D., Alsharekh, A.M., Crassard, R., Drake, N.A., Groucutt, H., Parker, A.G., Roberts, R.G., 2011. Middle Palaeolithic occupation on a Marine Isotope Stage 5 lakeshore in the Nefud Desert, Saudi Arabia. Quaternary Science Reviews 30, 1555-1559.

Petraglia, M.D., Alsharekh, A., Breeze, P., Clarkson, C., Crassard, R., Drake, N.A., Groucutt, H.S., Jennings, R., Parker, A.G., Parton, A., Roberts, R.G., Shipton, C., Matheson, C., Al-Omari, A., Veal, M.-A., 2012. Hominin dispersal into the Nefud desert and middle Palaeolithic settlement along the Jubbah palaeolake, northern Arabia. PLoS ONE 7, e49840, doi: 10.371/journal.ponr,0049840.

Philby, H.St.J.B., 1933. The Empty Quarter. Constable \& Company Ltd, London, $433 p p$.

Philippsen, B., 2013. The freshwater reservoir effect in radiocarbon dating. Heritage Science 1, 24pp.

Pint, A., Frenzel, P., Fuhrmann, R. Scharf, B., Wennrich, V., 2012. Distribution of Cyprideis torosa (Ostracoda) in Quaternary athalassic sediments in Germany and its application for palaeoecological reconstructions. International Review of Hydrobiology 97, 330-355.

Prescott, J., Hutton, J.T., 1994. Cosmic ray contributions to dose rates for luminescence and ESR dating: Large depths and long-term time variations. Radiation Measurements 23, 497-500.

Preusser, F., Kasper, H.U., 2001. Comparison of dose rate determination using highresolution gamma spectrometry and inductively coupled plasma-mass spectrometry. Ancient TL 19, 19-24.

Preusser, F., Radies, D., Matter, A., 2002. A 160,000-year record of dune development and atmospheric circulation in southern Arabia. Science 296, 2018-2020. 
890

891

892

893

894

895

896

897

898

899

900

901

902

903

904

905

906

907

908

909

910

911

912

913

914

915

916

917

918

919

920

921

922

Preusser, F., Chithambo, M.L., Götte, T., Martini, M., Ramseyer, K., Sendezera, E.J., Susino, G.J., Wintle, A.G., 2009. Quartz as a natural luminescence dosimeter. Earth Science Reviews 97, 196-226.

Preusser, F., Muru, M., Rosentau, A., 2014. Comparing different post-IR IRSL approaches for the dating of Holocene foredunes from Ruhnu Island, Estonia. Geochronometria 41, 342-351.

Rabus, B., Eineder, M., Roth, A., Bamler, R., 2003. The shuttle radar topography mission-a new class of digital elevation models acquired by spaceborne radar. Journal of Photogrammetry \& Remote Sensing 57, 241-262.

Radies, D., Preusser, F., Matter, A., Mange, M., 2004. Eustatic and climatic controls on the development of the Wahiba sand sea, Sultanate of Oman. Sedimentology 51, 1359-1385.

Radies, D., Hasiotis, S.T., Preusser, F., Neubert, E., Matter, A., 2005. Paleoclimatic significance of Early Holocene faunal assemblages in wet interdune deposits of the Wahiba sand sea, Sultanate of Oman. Journal of Arid Environments 62, 109-125.

Reimann, T., Tsukamoto, S., 2012. Dating the recent past ( $<500$ years) by post-IR IRSL feldspar - Examples from the North Sea and Baltic Sea coast. Quaternary Geochronology 10, 180-187.

Reimer, P. J., Bard, E., Bayliss, A., Beck, J. W., Blackwell, P. G., Bronk Ramsey, C., Buck, C. E., Cheng, H., Edwards, R. L., Friedrich, M., Grootes, P. M., Guilderson, T. G., Haflidason, H., Hajdas, I., Hatté, C., Heaton, T. J., Hoffmann, D. L., Hogg, A. G., Hughen, K. A., Kaiser, K. F., Kromer, B., Manning, S. W., Niu, M., Reimer, R. W., Richards, D. A., Scott, E. M., Southon, J. R., Staff, R. A., Turney, C. S. M., van der Plicht, J., 2013. IntCal13 and Marine13 radiocarbon age calibration curves 050,000 years cal References BP. Radiocarbon 55, 1869-1887.

Richter, D., Richter, A., Dornich, K., 2013. Lexsyg - A new system for luminescence research. Geochronometria 40, 220-228.

Rosenberg, T.M., Preusser, F., Blechschmidt, I., Fleitmann, D., Jagher, R., Matter, A., 2011a. Late Pleistocene palaeolake in the interior of Oman: a potential key area for the dispersal of anatomically modern humans out-of-Africa? Journal of Quaternary Science 27, 13-16.

Rosenberg, T.M., Preusser, F., Fleitmann, D., Schwalb, A., Penkman, K., Schmid, T.W., Al-Shanti, M.A., Kadi, K., Matter, A., 2011b. Late Pleistocene pluvial periods 

in southern Arabia: windows of opportunity for modern human dispersal. Geology 39, 1115-1118.

Rosenberg, T.M., Preusser, F., Risberg, J., Plikk, A., Kadi, K.A., Matter, A., Fleitmann, D., 2013. Middle and late Pleistocene humid periods recorded in palaeolake deposits of the Nafud desert, Saudi Arabia. Quaternary Science Reviews 70, 109-123.

Scerri, E.M.L., Breeze, P., Parton, A., Groucutt, H.S., White, T.S., Stimpson, C., Clark-Balzan, L., Jennings, R., Alsharekh, A., Petraglia, M.D., 2015. Middle to late Pleistocene human habitation in the western Nefud desert, Saudi Arabia. Quaternary International 382, 200-214.

Schulz, E., Whitney, J.W., 1986. Upper Pleistocene and Holocene lakes in the An Nafud, Saudi Arabia. Hydrobiologia 143, 175-190.

Stimpson, C., Breeze, P., Clark-Balzan, L., Groucutt, H.S., Jennings, R., Parton, A., Scerri, E., White, T.S., Petraglia, M.D., 2015. Stratified Pleistocene vertebrates with a new record of jaguar-sized pantherine (Panthera cf. gombaszogensis) from northern Saudi Arabia. Quaternary International 382, 168-180.

Szidat, S., Salazar, G. A., Vogel, E., Battaglia, M., Wacker, L., Synal, H.-A., Türler, A., 2014. ${ }^{14} \mathrm{C}$ analysis and sample preparation at the new Bern Laboratory for the Analysis of Radiocarbon with AMS (LARA). Radiocarbon 56, 561-566.

Tachikawa, T., Kaku, M., Iwasaki, A., Gesch, D., Oimoen, D., Zhang, Z., Danielson, J., Krieger, T., Curtis, B., Haase, J., Abrams, M., Crippen, R., and Carabajal, C., 2011. ASTER Global Digital Elevation Model Version 2 - Summary of Validation Results. METI \& NASA, 26pp.

Vincent, P., 2008. Saudi Arabia: An Environmental Overview. London, Taylor \& Francis Group, 309pp.

Wacker, L., Fülöp, R.-H., Hajdas I., Molnár, M., Rethemeyer, J., 2013. A novel approach to process carbonate samples for radiocarbon measurements with helium carrier gas. Nucl. Instrum. Methods B 294, 214-217.

Wallinga, J., Bos, A.J.J., Dorenbos, P., Murray, A.S., Schokker, J., 2007. A test case for anomalous fading correction in IRSL dating. Quaternary Geochronology 2, 216221. 
954 Webster, P.J., 2005. The elementary Hadley circulation. In: Diaz, H.F., Bradley, R.S.

955 (eds.), The Hadley Cell Circulation: Present, Past and Future, 9-60. Kluwer

956 Academic Publishers, Dordrecht, The Netherlands.

957 Whitney, J.W., 1983. Erosional history and surficial geology of Western Saudi Arabia.

958 Technical Record, USGS-TR-03-1, 90pp.

959 Wilson, I. G., 1973. Ergs. Sedimentary Geology 10, 77-106.

960 Wintle, A.G., Murray, A.S., 2006. A review of quartz optically stimulated

961 luminescence characteristics and their relevance in single-aliquot regeneration

962 dating protocols. Radiation Measurements 41, 369-391.

963 Zander, A., Degering, D., Preusser, F., Kasper, H.U., Brückner, H., 2007. Optically

964 stimulated luminescence dating of sublittoral and intertidal sediments from Dubai,

965 UAE.: Radioactive disequilibria in the uranium decay series. Quaternary

966 Geochronology 2, 123-128. 
968 Table 1. Radiocarbon dating results. Uncalibrated ${ }^{14} \mathrm{C}$ ages are given with one sigma 969 uncertainty. They are calibrated using the IntCal13 dataset (Reimer et al., 2013) and 970 presented as age ranges representing $2 \sigma$ confidence limits. * Significant calcite 971 contribution indicates post-depositional precipitation of carbonates, age is considered 972 as minimum estimate.

973

\begin{tabular}{|l|l|l|l|l|}
\hline Sample & Material & Lab Code & $\begin{array}{l}\text { Uncalibrated }{ }^{14} \mathrm{C} \text { age } \\
(\mathrm{yr} \mathrm{BP})\end{array}$ & $\begin{array}{l}\text { Calendar age range }(2 \sigma) \\
(\mathrm{yr} \mathrm{BP})\end{array}$ \\
\hline 4213.1 & Unio tigridis & $\mathrm{BE}-2751$ & $6630 \pm 50$ & $7430-7590$ \\
\hline 4213.1 & Melanoides tuberculata & $\mathrm{BE}-2752$ & $6600 \pm 60$ & $7420-7580$ \\
\hline 4213.2 & Unio tigridis & $\mathrm{BE}-2753$ & $7740 \pm 60$ & $8410-8610$ \\
\hline 4213.2 & Melanoides tuberculata & $\mathrm{BE}-2754$ & $7640 \pm 70$ & $8350-8580$ \\
\hline 4213.3 & Unio tigridis & $\mathrm{BE}-2755$ & $6360 \pm 50$ & $7170-7420$ \\
\hline 4213.3 & Melanoides tuberculata & $\mathrm{BE}-2756$ & $7430 \pm 70^{*}$ & $(8050-8380)$ \\
\hline 4214.2 & Bulinus & $\mathrm{BE}-2757$ & $7930 \pm 60$ & $8610-8990$ \\
\hline 4214.3 & Unio tigridis & $\mathrm{BE}-2758$ & $7770 \pm 60$ & $8410-8650$ \\
\hline 4214.3 & Melanoides tuberculata & BE-2759 & $7760 \pm 70$ & $8400-8700$ \\
\hline
\end{tabular}


976 Table 2. Summary data of luminescence dating with sampling depth below surface, the grain size used for Equivalent dose $\left(D_{e}\right)$ determination, the number

977 of aliquots used for calculation of mean $\mathrm{D}_{e}$, and the concentration of dose rate relevant elements (K, Th, U). U-238 = concentration of Uranium as deduced

978 from the U-235 peak at $186 \mathrm{keV}$, U-post Ra = as deduced from post-Ra-226 isotopes Bi-214 and Pb-214 (cf. Preusser and Kasper, 2001; Zander et al., 2007).

979 Given is the total annual dose rate (D) for both IRSL/pIR and OSL, observed overdispersion, the age model $(\mathrm{C}=\mathrm{Central}$ Age Model, $\mathrm{M}=\mathrm{Minimum}$ Age

980 Model) being used and the resulting mean $\mathrm{D}_{\mathrm{e}}$ and age for the three different approaches.

981

\begin{tabular}{|c|c|c|c|c|c|c|c|c|c|c|c|c|c|c|c|c|c|}
\hline mple & $\begin{array}{r}\text { Depth } \\
(\mathrm{cm})\end{array}$ & $\begin{array}{c}\text { Grain size } \\
(\mu \mathrm{m})\end{array}$ & $\begin{array}{c}\mathrm{n} \\
\mathrm{F} / \mathrm{Q}\end{array}$ & $\begin{array}{l}\mathrm{K} \\
(\%)\end{array}$ & $\begin{array}{c}\text { Th } \\
(\mathrm{ppm})\end{array}$ & $\begin{array}{l}\mathrm{U}-238 \\
(\mathrm{ppm})\end{array}$ & $\begin{array}{c}\text { U-post Ra } \\
\text { (ppm) }\end{array}$ & $\begin{array}{l}\text { D IRSL } \\
\left(\mathrm{Gy} \mathrm{ka}^{-1}\right)\end{array}$ & $\begin{array}{c}\text { D OSL } \\
\left(\mathrm{Gy} \mathrm{ka}^{-1}\right)\end{array}$ & $\begin{array}{l}\text { od } \\
(\%)\end{array}$ & Model & $\begin{array}{c}\mathrm{D}_{\mathrm{e}} \text { IRSL } \\
\text { (Gy) }\end{array}$ & $\begin{array}{c}D_{e} p I R \\
(G y)\end{array}$ & $\begin{array}{c}\mathrm{D}_{\mathrm{e}} \mathrm{OSL} \\
(\mathrm{Gy})\end{array}$ & $\begin{array}{c}\text { Age IRSL } \\
\text { (ka) }\end{array}$ & $\begin{array}{c}\text { Age pIR } \\
\text { (ka) }\end{array}$ & $\begin{array}{c}\text { Age OSL } \\
\text { (ka) }\end{array}$ \\
\hline
\end{tabular}

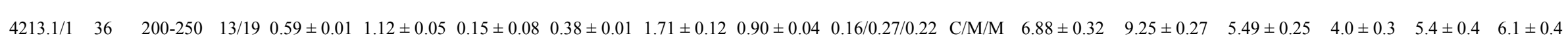

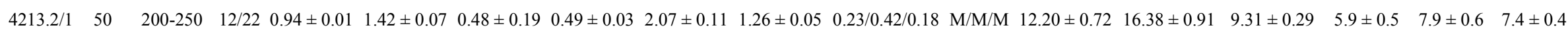

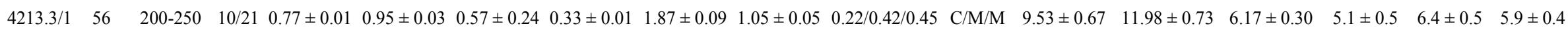

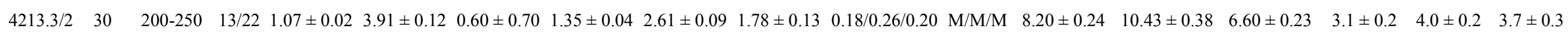

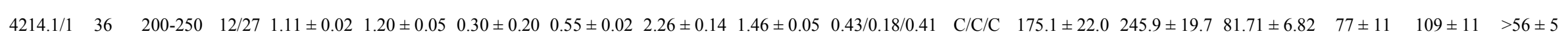

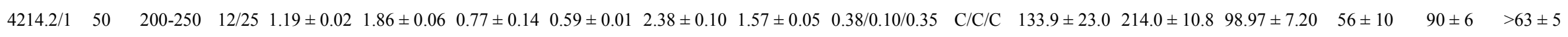

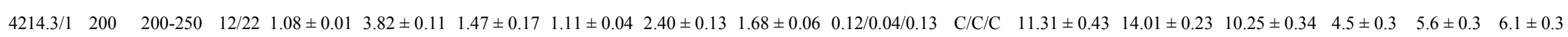

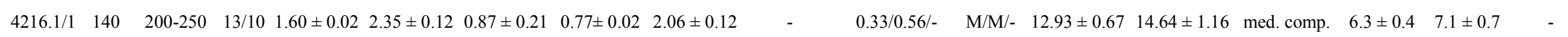

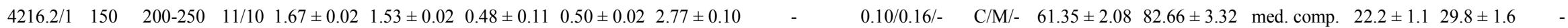


986 Fig. 1. a) Digital elevation model of the Arabian Peninsula derived from SRTM data.

987 b) Palaeodrainage network and catchment areas of Wadi ad Dawasir and Wadi as

988 Sahba systems, including the locations of sites and Figs. 2 and 3 (superimposed over

989 SRTM elevation data, DEM on shaded-relief map). The DEM-derived drainage

990 network (contributing area of $>150 \mathrm{~km}^{2}$ ) was combined and complemented by other

991 river courses than were inferred from the flow directions in areas with intermittent

992 dune coverage (see examples in Fig. 2). Large sink areas and dune-dominated areas

993 with interdune depressions deliver erroneous stream lines within the derived drainage

994 network and were removed.

995

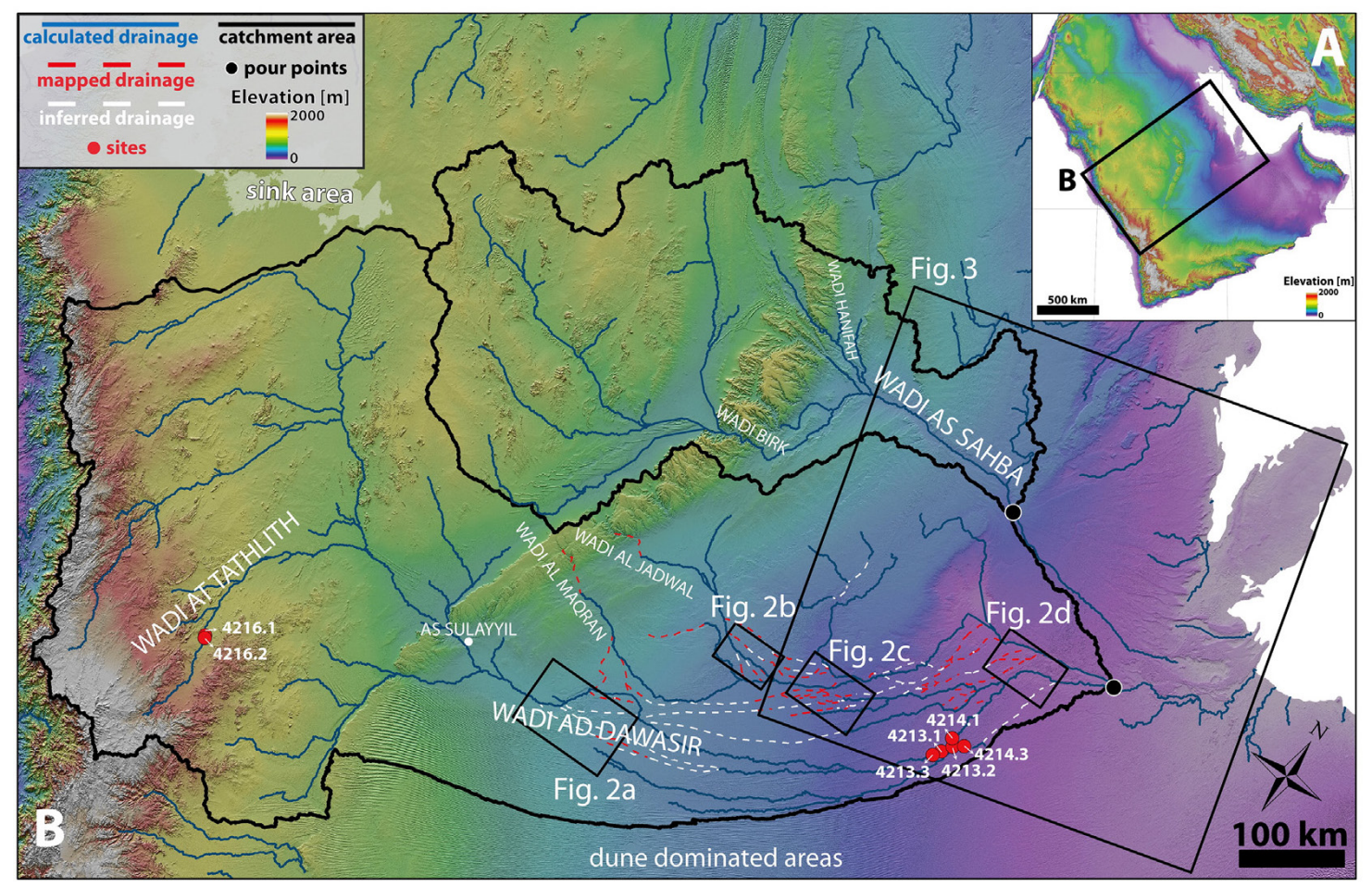


999 Fig. 2. Example areas with only minor or incomplete sand coverage. Landsat 7 FCCs

1000 clearly show a stark contrast between sand coverage and underlying palaeodrainage

1001 systems that were used to determine (A) and map (C) recent and palaeostream systems

1002 as well as flow directions (B) (RGB composites with a band combination of 7/4/2 and

$10033 / 2 / 1$, histograms are stretched to display extent). Digital elevation data and derived

1004 hillshade images were additionally used to retrace drainage systems if underlying

1005 palaeochannels lead to inverse topography (D) (SRTM DEM on shaded-relief map).

1006

1007

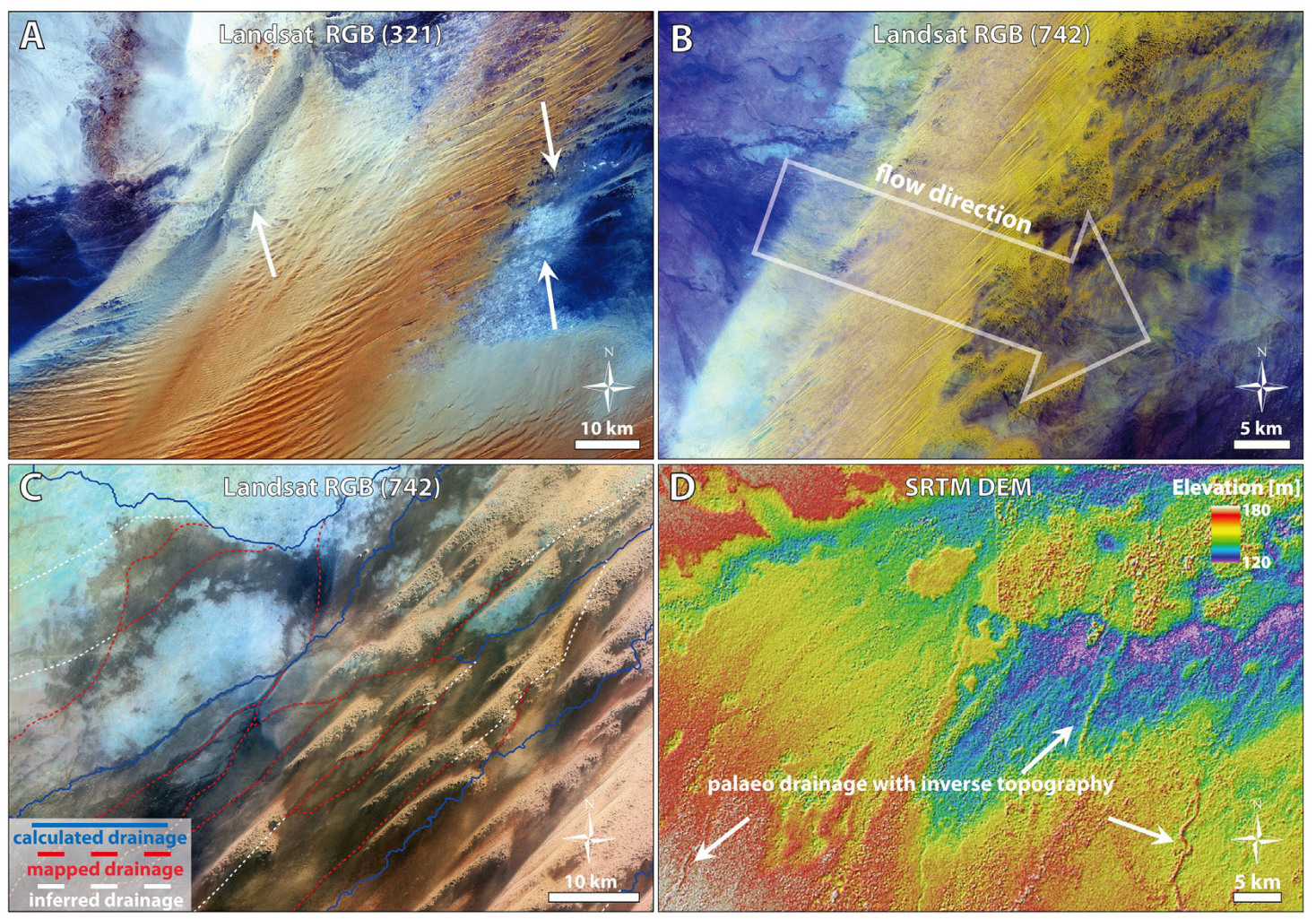

1008 
1009 Fig. 3. Map of drainage network and catchment areas of downstream areas of Wadi ad

1010 Dawasir and Wadi as Sahba systems (superposed over SRTM elevation data, DEM on

1011 shaded-relief map). The Sahba fan acts as barrier forcing the Dawasir channels to flow

1012 eastwards into the western margin of the Sabkha Matti. The present day channel of

1013 Wadi as Sahba runs across the fan towards the Al Humr lake, but the large extent of

1014 the Sahba fan indicate a high erosion rate, high runoff and transport capacity in former

1015 times.

1016

1017

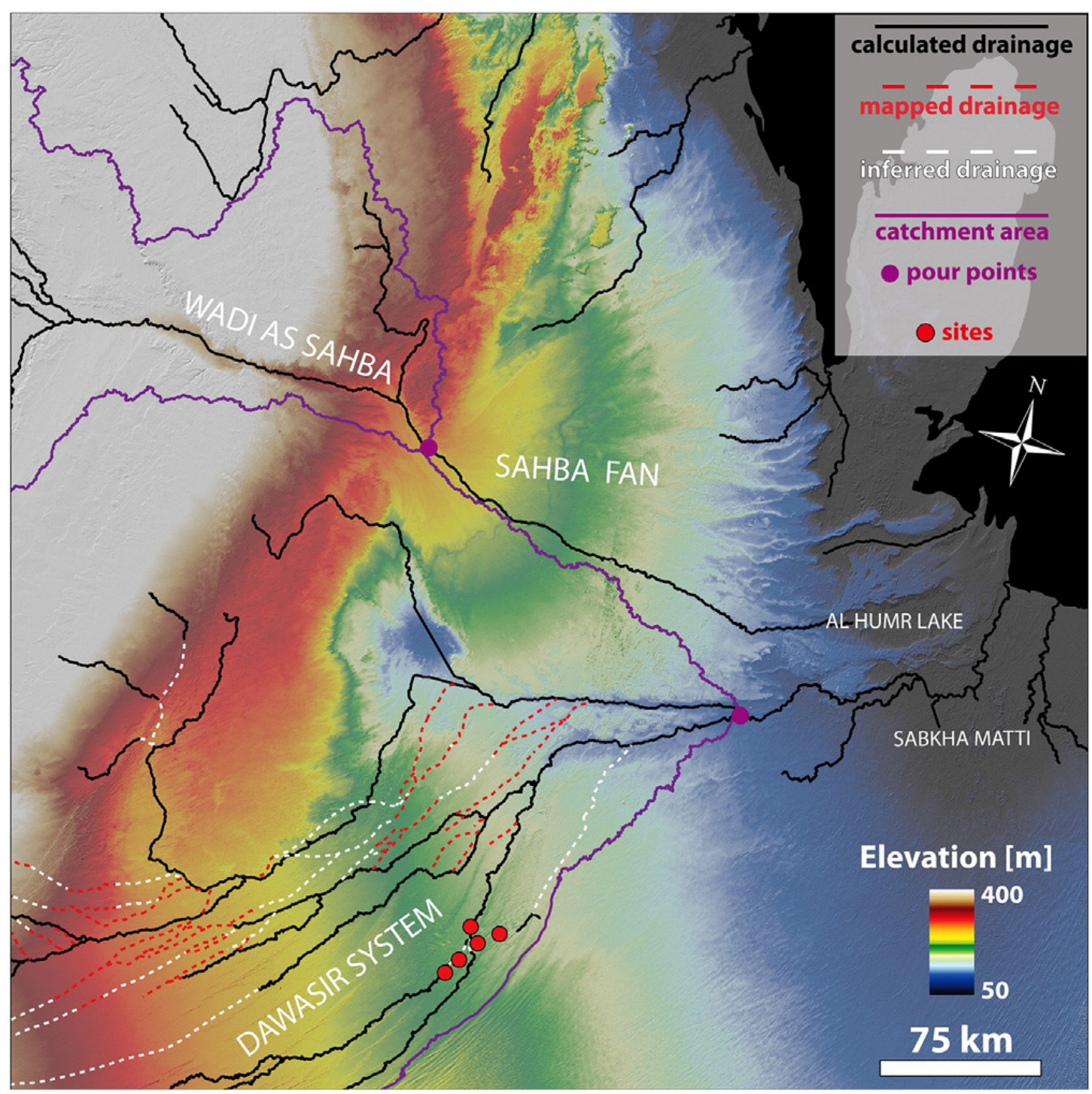

1018 
1019 Fig. 4. Characterisation of the luminescence properties of the investigated samples: a)

1020 OSL decay curve of sample 13.2/1 exemplifying the dominance of the fast component

1021 in most of the samples; b) OSL decay curve of sample 16.1/1 revealing low signal

1022 level and the strong presence of a medium component; c) typical IRSL and d) typical

1023 pIR decay curves shown for sample 4214.2/1; e) OSL dose response curve close to

1024 saturation and f) pIR dose response of the sample 4214.2/1.

1025
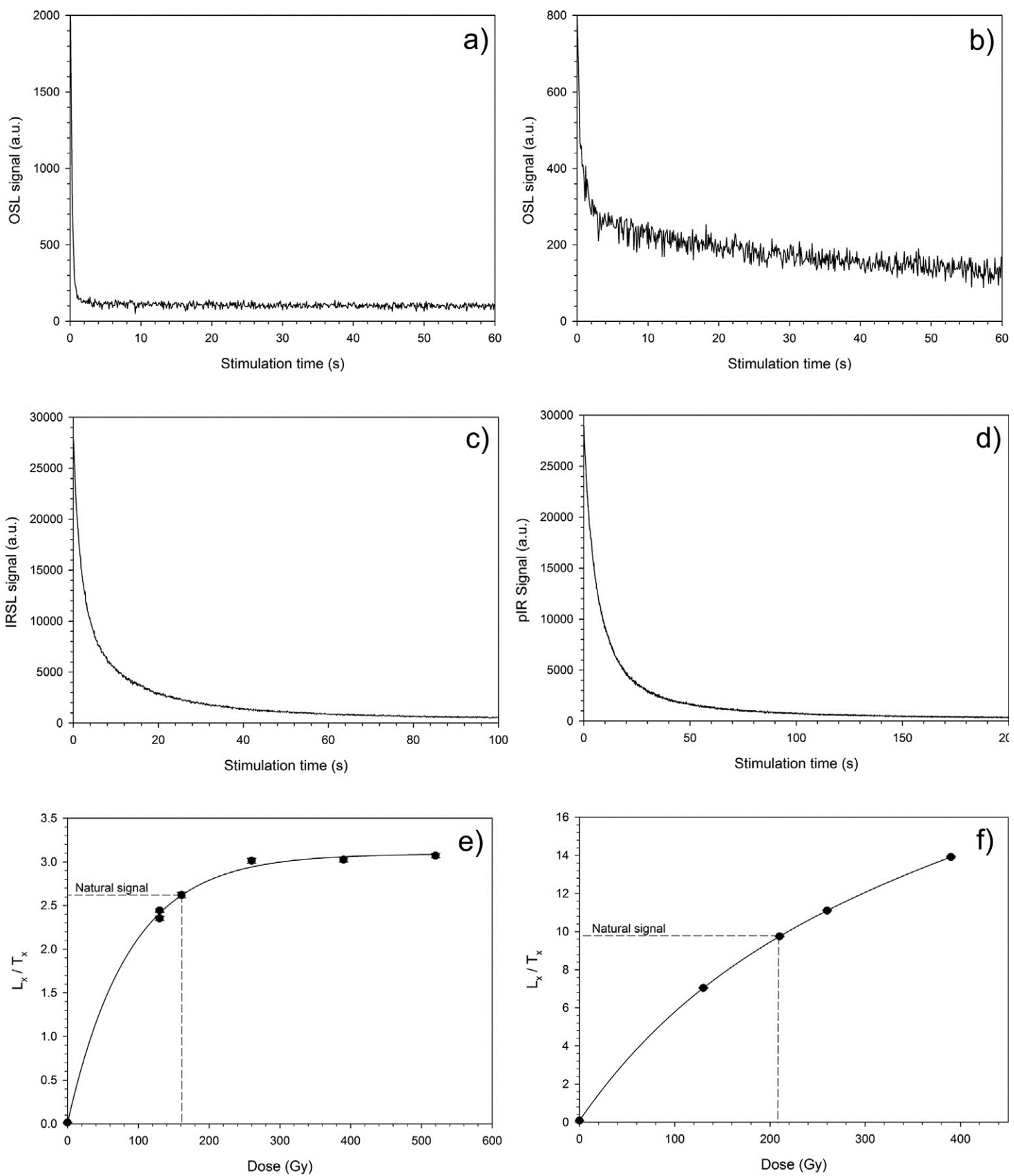
1028 Fig. 5. Two examples of OSL $D_{e}$ distributions for samples a) 4213.1/1 and b) 4213.3/3. 1029

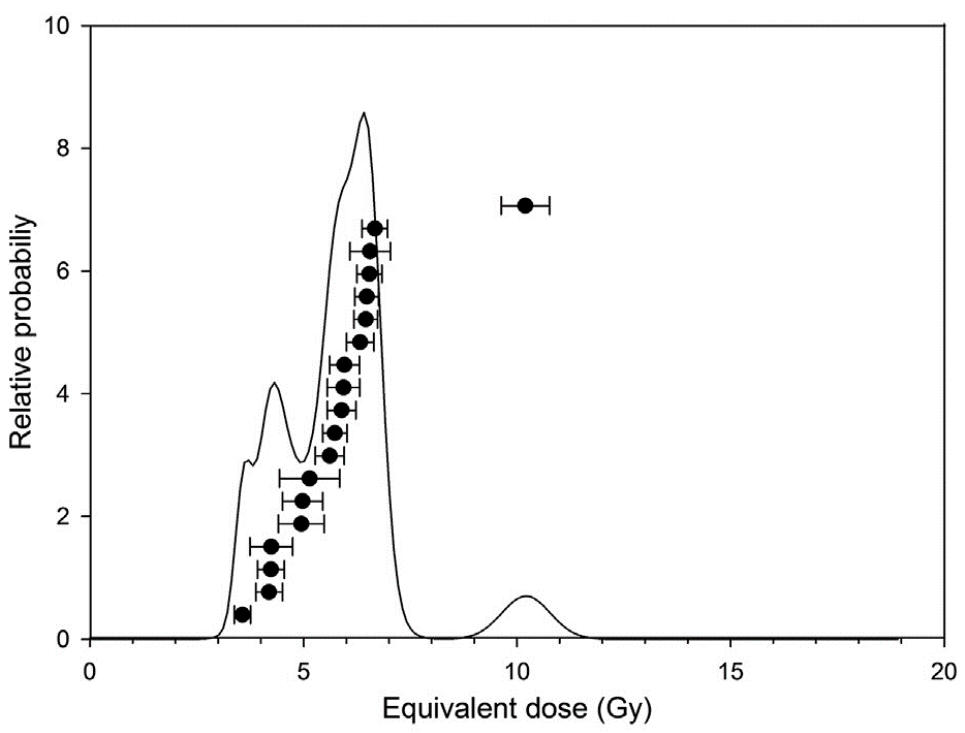

1030

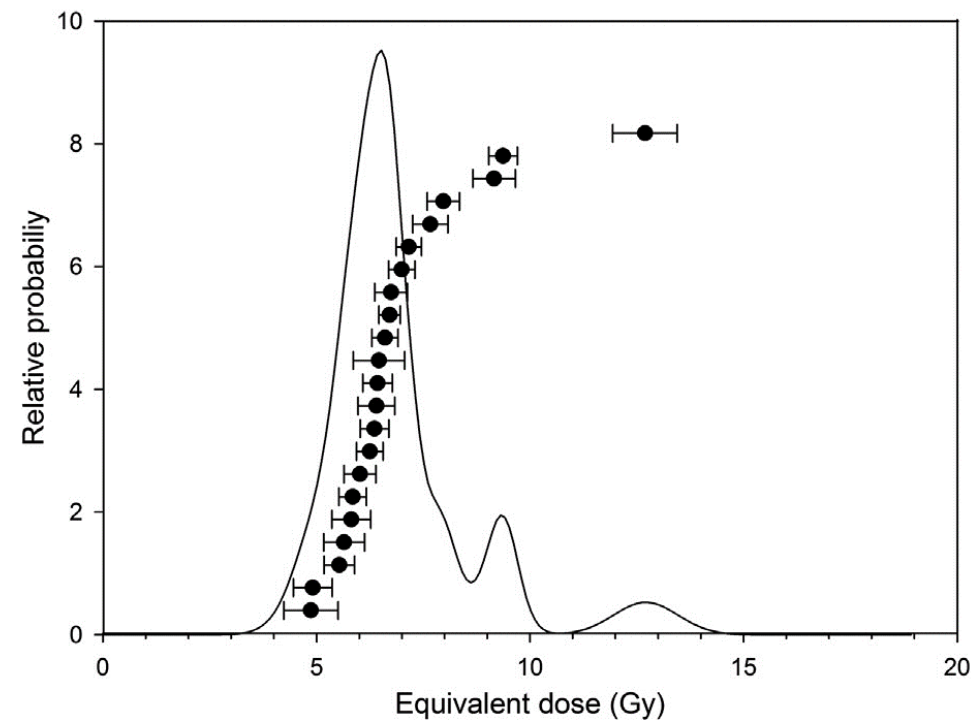

1031 
1032 Fig. 6. Vertical lithological sections in the distal Wadi ad Dawasir. For locations see

1033 Fig. 1B and for legend Fig. 8. Grain size classification abbreviations: crsSU Coarse

1034 Sand (Upper) 710-1000 $\mu \mathrm{m}$; crsSL Coarse Sand (Lower) 500-710 $\mu \mathrm{m}$; mSU Medium

1035 Sand (Upper) 350-500 $\mu \mathrm{m}$; mSL Medium Sand (Lower) 250-350 $\mu \mathrm{m}$; fSU Fine Sand 1036 (Upper) 177-25 $\mu \mathrm{m}$.

1037

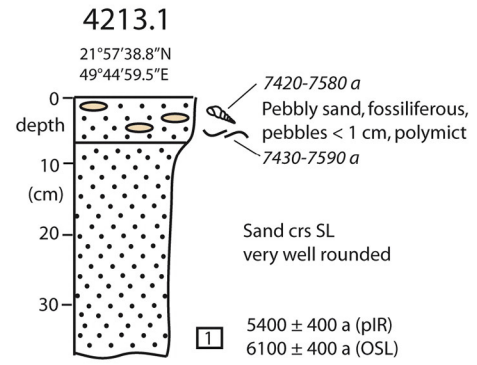

4213.3

$21^{\circ} 53^{\prime} 37.4^{\prime \prime} \mathrm{N}$

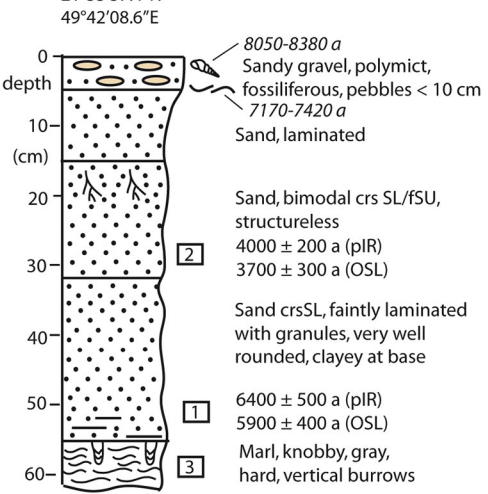

4214.2

$22^{\circ} 06^{\prime} 17.8^{\prime \prime} \mathrm{N}$

$49^{\circ} 54^{\prime} 02.5^{\prime \prime} \mathrm{E}$

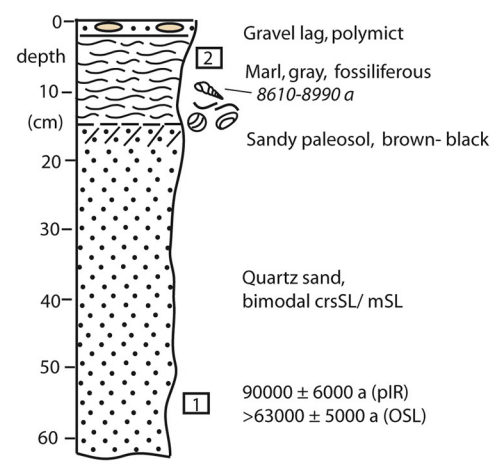

1038

1039
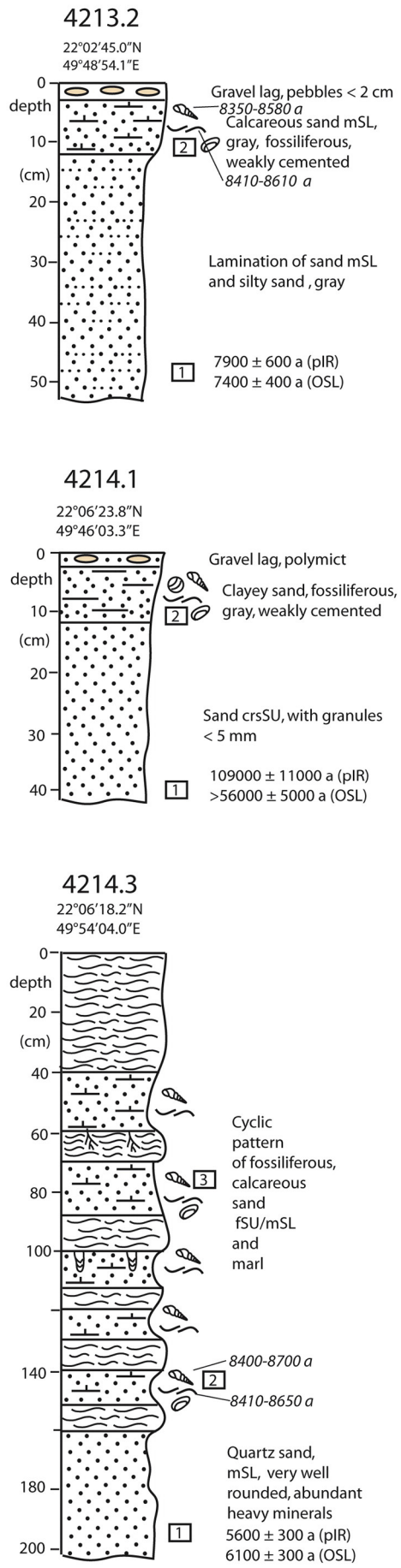
1040 Fig. 7. Bing map satellite view showing location of site 4213.3 in Holocene channel

1041 partly covered by younger linear dune (A), photographs showing surface with pebble

1042 lag, M. tuberculata and U. tigridis in-situ position measuring $4 \mathrm{~cm}$ (B) of relict channel

1043 at site 4213.2 (C). Outcrop view of relict lacustrine section site 4214.3 measuring 2

1044 metres (D). Photograph of vertical fluvial section in lower terrace at site 4216.1 in

1045 Wadi at Tathlith with pedogenic horizons. Note hammer for scale (E). Panoramic view

1046 looking E across ponded Holocene alluvial sandy silts in Wadi at Tathlith, $30 \mathrm{~km}$

1047 upstream of site 4216.1 (F).

1048
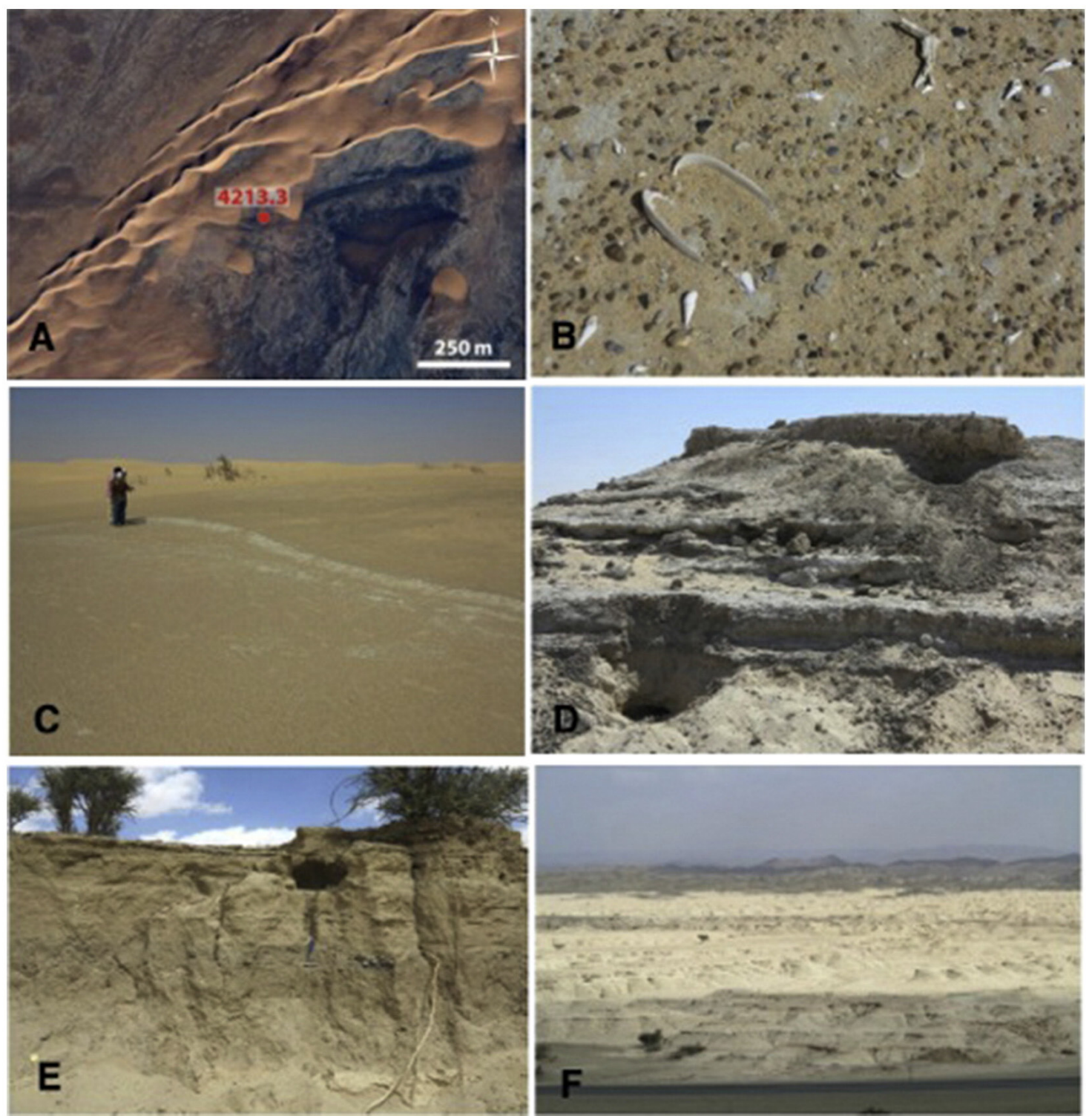
1051 Fig. 8. Vertical lithological sections in Wadi at Tathlith. For locations see Fig. 1B.

1052
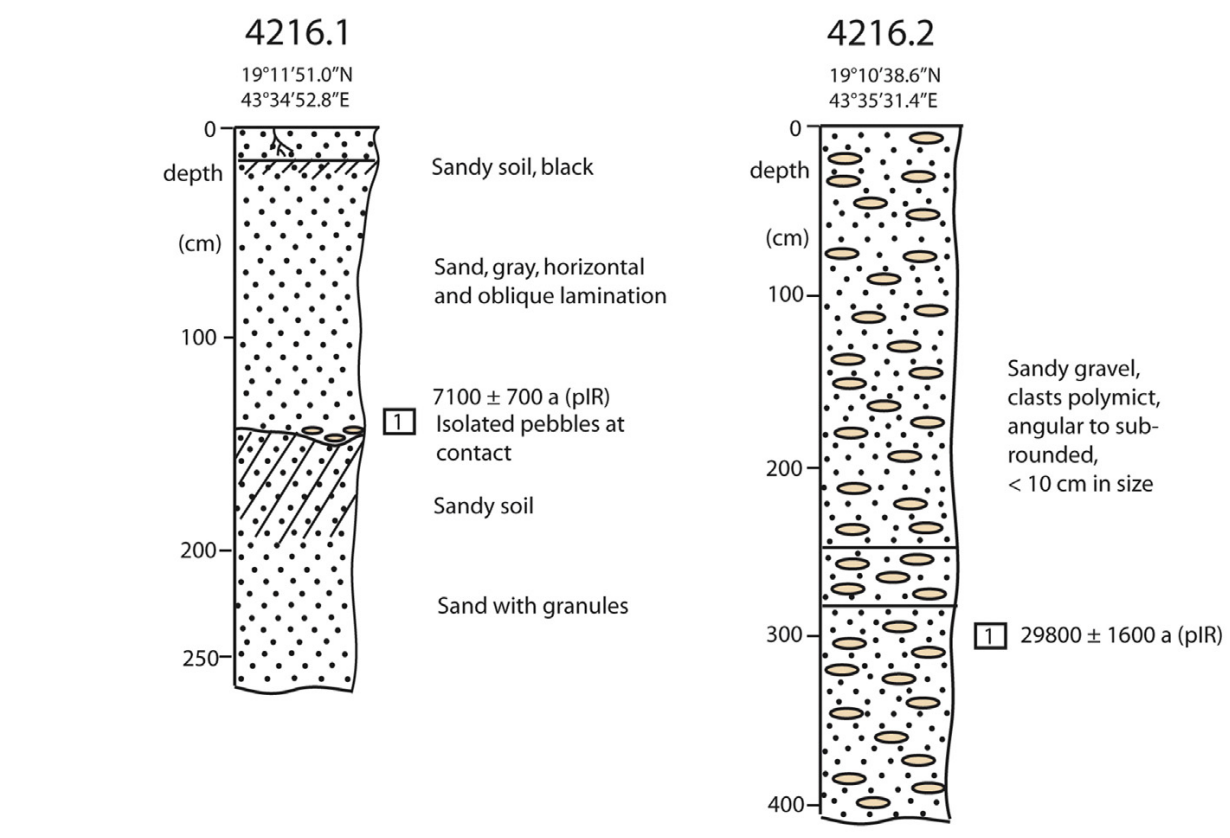

1053

1054

\begin{tabular}{|c|c|}
\hline \multicolumn{2}{|c|}{ Legend } \\
\hline$\sim$ & Marl \\
\hline 8 & Gravel \\
\hline$\because \div$ & Sand/ calc. sand \\
\hline$\because \because:$ & Silty sand \\
\hline$=$ & Clay \\
\hline 3 & Burrows \\
\hline PA & Soil \\
\hline$\hat{A}$ & Rootlets \\
\hline$\infty$ & Gastropods \\
\hline थ & Bivalves \\
\hline (2) & Charophytes \\
\hline$\theta$ & Ostracodes \\
\hline $7420-7580$ & $\begin{array}{l}\text { Radiocarbon age } \\
\text { (cal BP) }\end{array}$ \\
\hline $7100 \pm 700$ & $\begin{array}{l}\text { Luminescence } \\
\text { age }\end{array}$ \\
\hline
\end{tabular}


1055 Fig. 9. OSL and pIR ages plotted in comparison to radiocarbon ages and revealing the 1056 substantial off-set between the methods. A significant calcite contribution indicates 1057 post-depositional precipitation of carbonates for sample 4213.3 Melanoides 1058 tuberculata. The curve on top is the isotope signature of a stalagmite from Qunf cave 1059 (Fleitmann et al., 2007), showing the gradual decrease in precipitation in southern 1060 Arabia during the middle Holocene.

1061

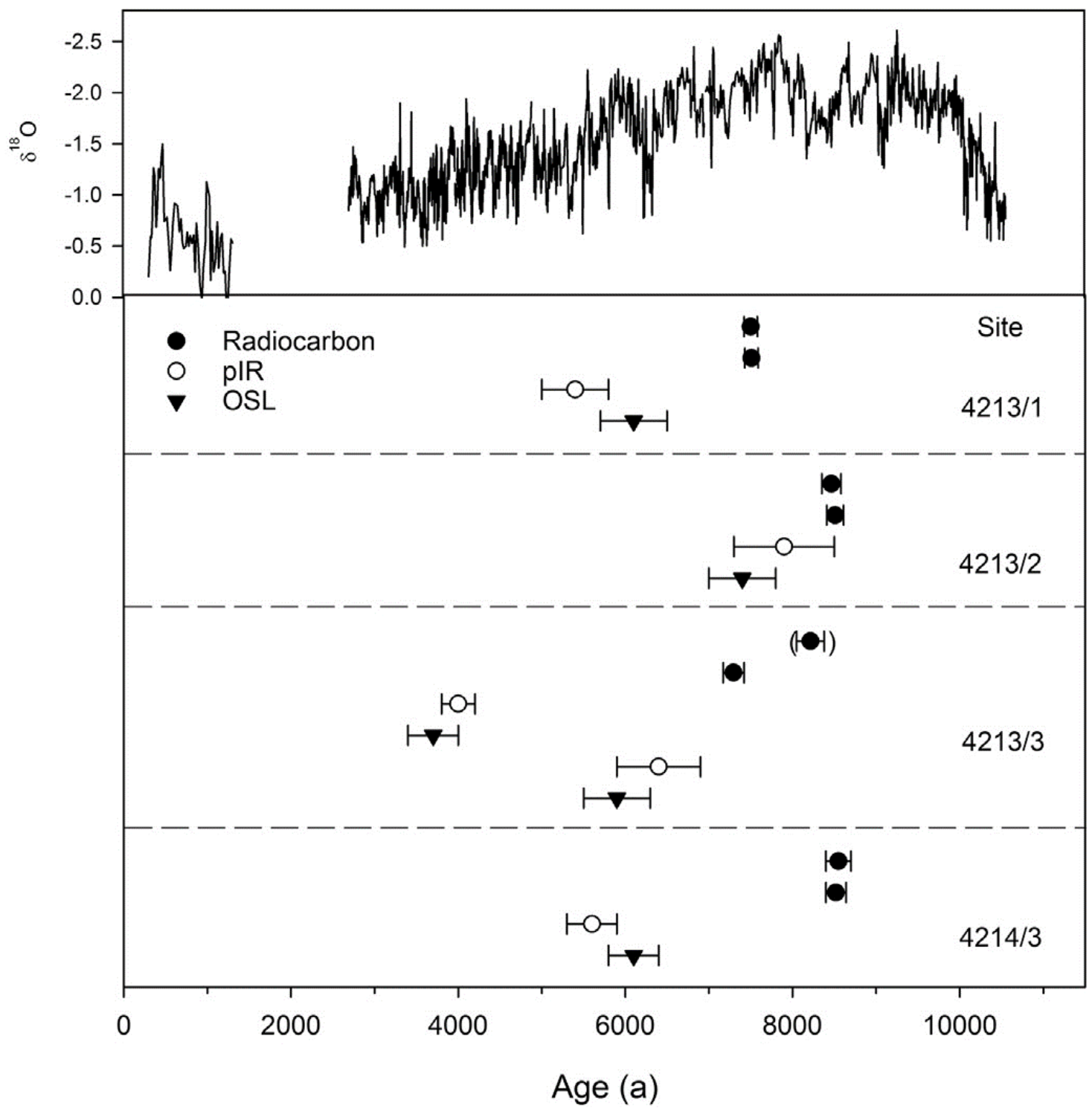

